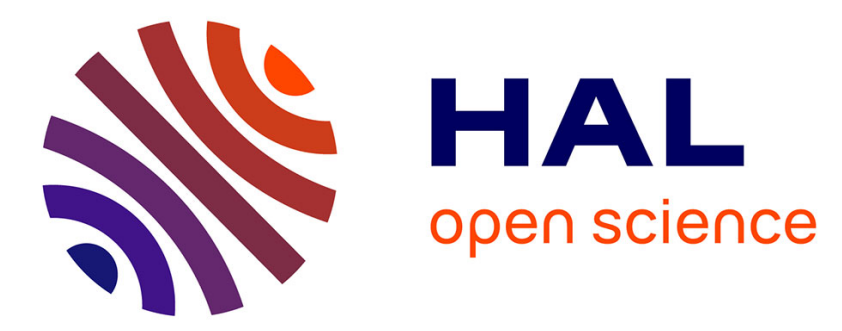

\title{
The Use of Resorcinarene Cavitands in Metal-Based Catalysis
}

Nallusamy Natarajan, Eric Brenner, David Sémeril, Dominique Matt, Jack Harrowfield

\section{> To cite this version:}

Nallusamy Natarajan, Eric Brenner, David Sémeril, Dominique Matt, Jack Harrowfield. The Use of Resorcinarene Cavitands in Metal-Based Catalysis. European Journal of Organic Chemistry, 2017, 2017 (41), pp.6100-6113. 10.1002/ejoc.201700725 . hal-03545210

\section{HAL Id: hal-03545210 https://hal.science/hal-03545210}

Submitted on 27 Jan 2022

HAL is a multi-disciplinary open access archive for the deposit and dissemination of scientific research documents, whether they are published or not. The documents may come from teaching and research institutions in France or abroad, or from public or private research centers.
L'archive ouverte pluridisciplinaire HAL, est destinée au dépôt et à la diffusion de documents scientifiques de niveau recherche, publiés ou non, émanant des établissements d'enseignement et de recherche français ou étrangers, des laboratoires publics ou privés. 
Microreview

\section{The use of resorcinarene-cavitands in metal-based catalysis}

Graphical abstract
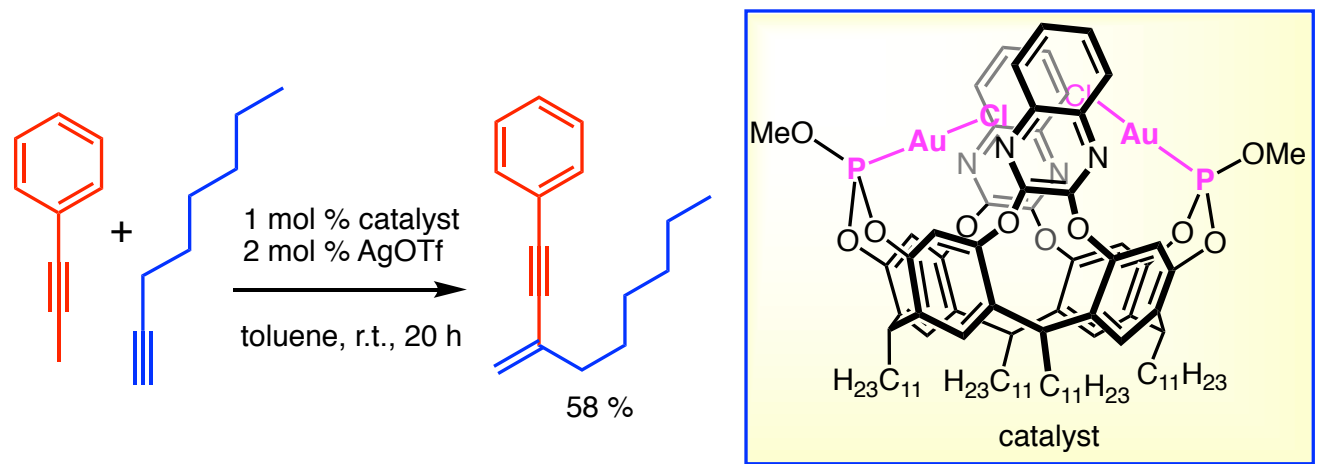

The utility of resorcinarene cavitands in catalysis arises from: i) their ability to create metal confinement and thus to make reactions either shape selective or to enhance their rates through supramolecular assistance by the receptor subunit; ii) their ability to enforce steric interactions with a coordinated metal centre and thereby favour carbon-carbon bond forming reactions. This review gives an overview on the promise that exists in this area. 


\title{
Microreview
}

\section{The use of resorcinarene-cavitands in metal-based catalysis}

Natarajan Millusamy, ${ }^{a}$ Eric Brenner ${ }^{a}$ David Sémeril, ${ }^{* a}$ Dominique Matt, ${ }^{* a}$ Jack Harrowfield ${ }^{b}$

\begin{abstract}
Catalytic chemistry involving coordination complexes based on resorcinarene cavitands has been little explored in comparison to the many studies concerning the use of such ligands in classical coordination chemistry or host-guest chemistry. The potential utility of resorcinarene cavitands in catalysis arises essentially from two features: i) their ability to function as ligands suitable for metal confinement and thus to make reactions either shape selective or to enhance their rates through supramolecular assistance by the receptor subunit; ii) their ability to enforce steric interactions with a coordinated metal centre and thereby favour carbon-carbon bond forming reactions. To date, limited use has been made of cavitands as platforms for the attachment of different ligating sites, in particular for the generation of multifunctional ligands giving rise to anchimeric assistance in catalytic reactions. This review is intended to show the promise that exists in this area. As generic cavitands can be easily expanded to result in large bowl-shaped structures as well as capsular containers, it may be anticipated that future work in this field will focus on the synthesis of sophisticated, metallated microreactors (possibly made water-soluble) for highly selective transformations, including polymerisations.
\end{abstract}

${ }^{[a]}$ Université de Strasbourg, Laboratoire de Chimie Inorganique Moléculaire et Catalyse, UMR 7177 CNRS, 4 rue Blaise Pascal, 67008 Strabourg cedex, France

E-mail:dmatt@unistra.fr,dsemeril@unistra.fr

http://lcimc.u-strasbg.fr

${ }^{[\mathrm{b}]}$ Université de Strasbourg, ISIS, UMR 7006 CNRS-ULP, 8 allée Gaspard Monge, BP 70028, F-67083, Strasbourg cedex 


\section{Introduction. Synthesis and properties of generic resorcinarenes and resorcinarene-cavitands}

Resorcinarenes are a class of macrocycles first correctly identified in $1940{ }^{[1]}$ although their chemistry can be traced back to work of Baeyer in the nineteenth century. ${ }^{[2]}$ Typically, these compounds can be obtained in high yields by condensation of resorcinol or its derivatives and an aldehyde in EtOH/ $\mathrm{H}_{2} \mathrm{O}$ under acidic conditions, the thermodynamically strongly favoured end product from an initially complex mixture of linear species being the macrocycle resulting from condensation of four units each of resorcinol and aldehyde (Scheme 1), ${ }^{[3]}$ although under certain conditions a less stable macrocycle incoprporating six units can be isolated. ${ }^{[4]}$ In fact, the use of a solvent for their preparation is not mandatory, ${ }^{[5]}$ although solvent-free synthesis may result in inseparable mixtures of isomers. ${ }^{[6]}$ Methods for their functionalisation have been widely explored so that numerous very sophisticated derivatives have become accessible. ${ }^{[7]}$ The first crystallographic characterisation of a resorcinarene was reported in 1968 (Fig. 1). ${ }^{[8]}$

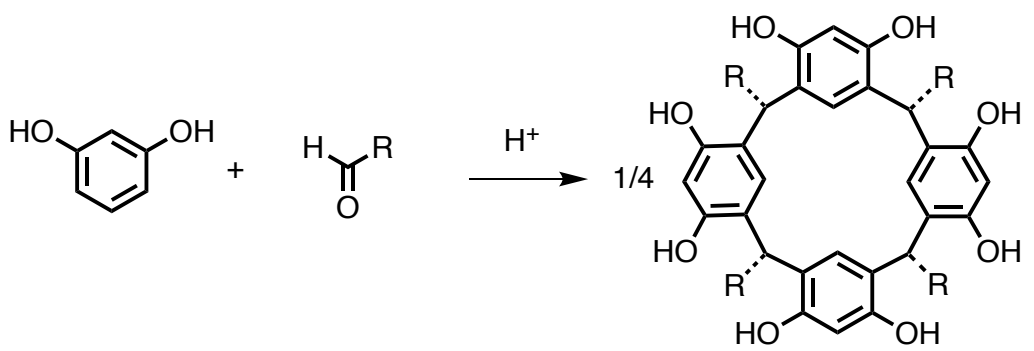

Scheme 1. Synthesis of resorcinarenes

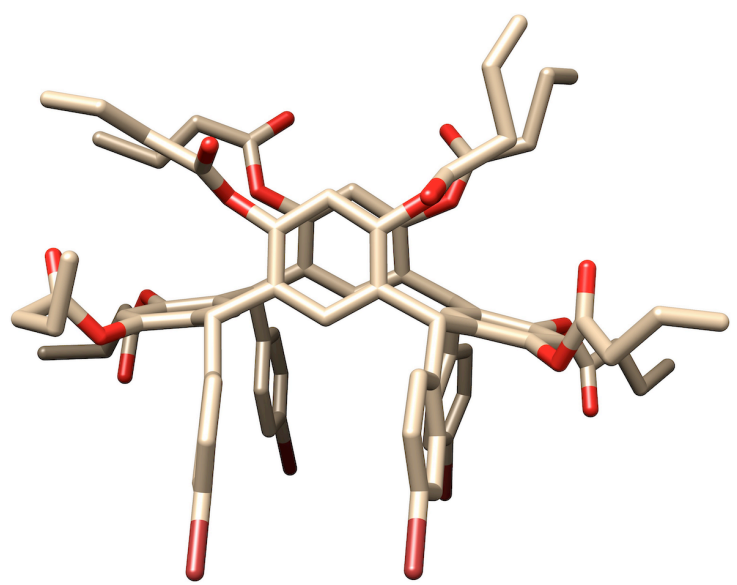

Figure 1. Molecular structure within the crystal of the product of reaction of resorcinol with 4bromobenzaldehyde (after butanoylation of all hydroxyl groups).

The stereochemistry of the resorcinarenes is complicated both by the facts that the substituents on the bridging units may adopt different relative orientations (usually defined with respect to the mean plane of the macrocycle) and that facile rotation about the $\mathrm{C}-\mathrm{C}$ bonds linking the aromatic rings to the bridging atoms leads to several conformational minima. Hydrogen bonding is also an important stereochemical influence in parent resorcinarenes where hydroxyl groups are retained. The rapid equilibration between different isomers in acidic media coupled to differences in solubility can, however, mean that a single species can 
be crystallised in good yield from a given reaction mixture. ${ }^{[3,9]}$ Importantly, this is usually the cis,cis,cis isomer, the formal precursor to all bowl-shaped cavitands. The conformational flexibility of generic resorcinarenes is revealed in numerous solid state structure determinations (321 currently in the CSD, plus several thousand for derivatives) by X-ray diffraction where the conformation varies considerably depending on associated molecules present in the lattice as well as the nature of the bridge substituent. Thus, for example, for the simplest resorcinarene, generated from acetaldehyde and resorcinol, as the cis,cis,cis isomer, it has been found in several instances ${ }^{[10]}$ to adopt a crown or cone conformation close to $C_{4 v}$ symmetry, in others ${ }^{[11]} C_{2 v}$-symmetric conformations varying between a "flattened" cone (when the distortion is slight) and a boat or saddle forms (as seen also in Figure 1) where greater distortion occurs, as well as to adopt a chair form of at most $C_{s}$ symmetry. ${ }^{[12]}$ With bridge substituents other than methyl, as well as for isomers other than the cis,cis,cis, a similar range of conformations is known ${ }^{[13]}$ the chair form of the cis,trans, cis isomer with 4hydroxyphenyl substituents, for example, being established in early work. ${ }^{[14]}$ Some examples of conformations established by X-ray crystallography for the cis,cis, cis isomer of the tetramethyl resorcinarene are given in Figure 2.

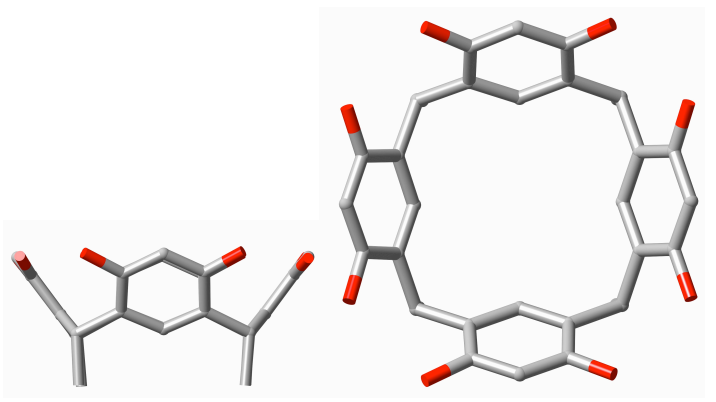

(a)

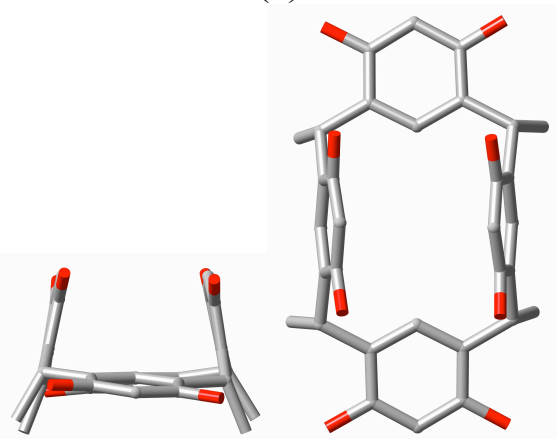

(c)

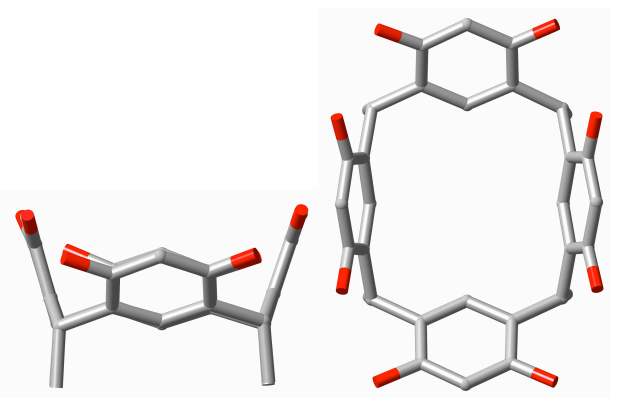

(b)

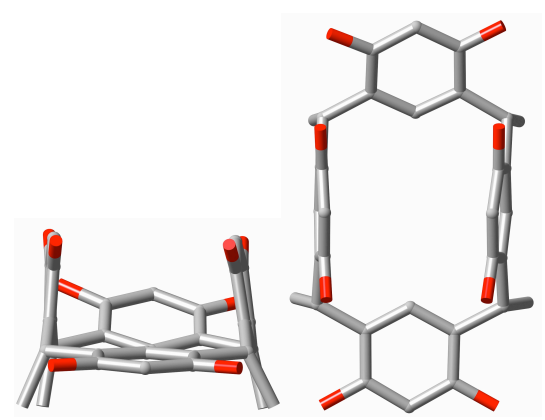

(d)

Figure 2. Orthogonal views of the conformations of the cis,cis,cis isomer of tetramethylresorcinarene found in different solid state adducts. For clarity, H-atoms are omitted. (a) A conformer of near $C_{4 \mathrm{v}}$ symmetry; ${ }^{[10 \mathrm{a}]}(b)$, (c) increasingly distorted conformers of near $C_{2 \mathrm{v}}$ symmetry; ${ }^{[11 \mathrm{~b}, 11 \mathrm{c}]}(d)$ a chairlike conformer of $C_{\mathrm{s}}$ symmetry. ${ }^{[12]}$

Modification of the cis,cis, cis resorcinarene core was first achieved by introduction of methylene bridges between oxygen atoms of adjacent resorcinolic rings. ${ }^{[9 a]}$ The term "cavitand" was coined to describe these materials which, locked into a symmetrical cone conformation, were considered to define a rigid molecular cavity. ${ }^{[15]}$ Heteroatoms, ${ }^{[9 a, 15 a, 15 b, 16]}$ hydrocarbon chains, ${ }^{[17]}$ phenylene ${ }^{[18]}$ or quinoxaline-diyl ${ }^{[19]}$ units can also be used for linking 
the resorcinol rings and thus create a cavitand (Fig. 3). While inhibiting conformational changes of the resorcinarene core, these links can be associated with their own conformational equilibria giving rise to control of the cavitand's behaviour as a receptor, as seen with the "vase" and "kite" forms of the quinoxaline-bridged species. ${ }^{[20]}$ Combined with the rigidity of cavitands, the many possible variations in the bridging groups has been the basis of the continual development of cavitand chemistry over the past 4 decades. Major advances have concerned : a) the ability of many resorcinarene-cavitands to function as receptors towards small molecules and ions; ${ }^{[21]} \mathrm{b}$ ) the ease of extension of the core for the construction of larger container molecules for the encapsulation of neutral and ionic compounds, ${ }^{[22]}$ including metal complexes ${ }^{[23]}$ c) the ease with which they can be selectively functionalised at inequivalent sites, facilitating the synthesis of sophisticated multitopic ligands. ${ }^{[7,24]}$ The ease of linking resorcinarene units one to another has of course been the basis of the development of the major field of carcerand chemistry. ${ }^{[22 a, 22 d, 25]}$
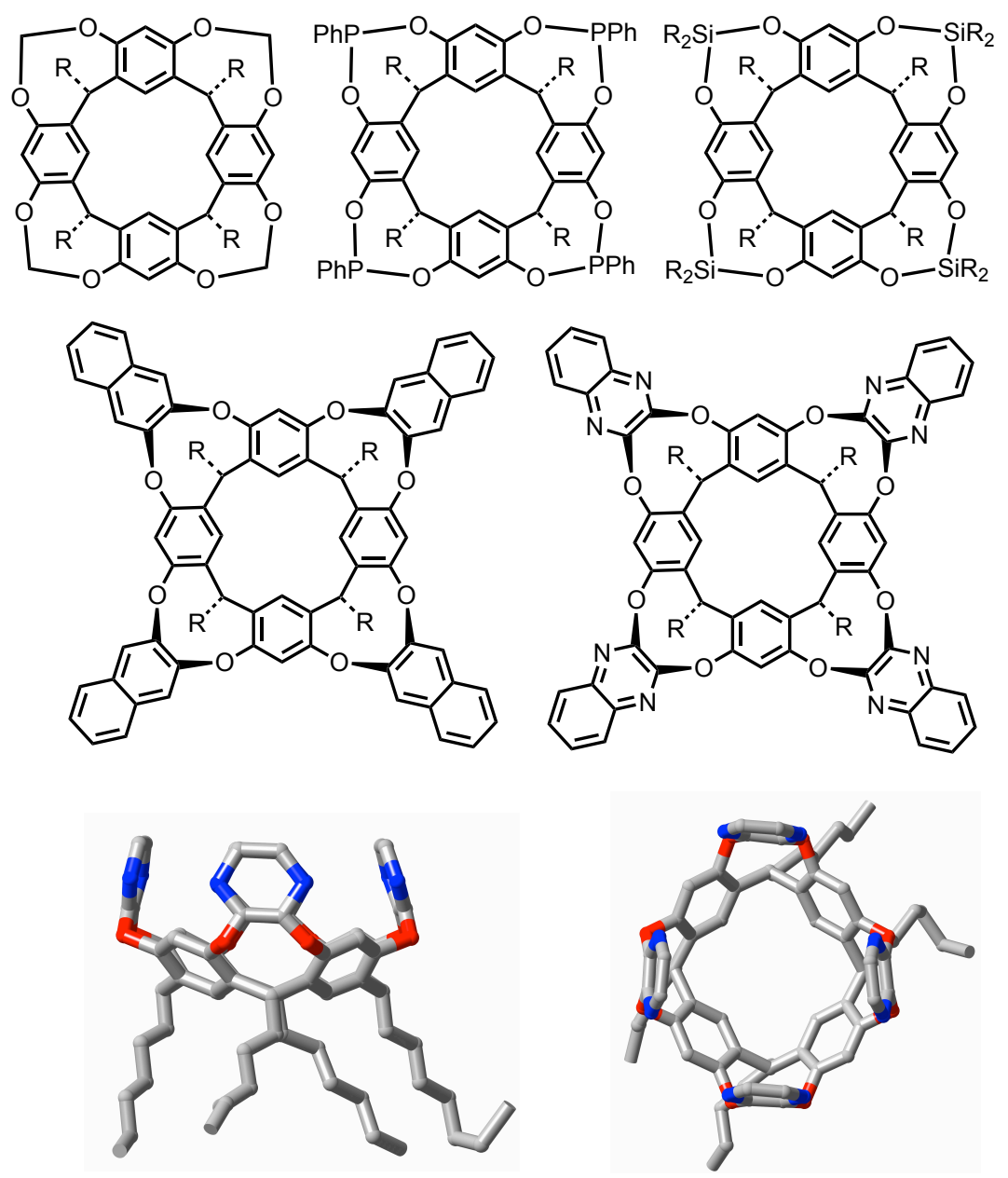

Figure 3. (Upper) Examples of resorcinarene-based cavitands; (Lower) Orthogonal views of the molecular species with the lattice of a vase-form pyrazine-bridged cavitand, ${ }^{[26]}$ showing the well-formed, symmetrical cavity.

The following pages provide a survey on the catalytic applications of ligands based on the resorcinarene cavitand platform. While extensive studies have been made of equilibrium binding, catalysis based on metal ion complexes of cavitands has, in contrast to the situation 
for ligands based on the similar calix[4]arene core, ${ }^{[17]}$ been given quite limited attention. ${ }^{[7,27]}$ Catalysis employing non-rigidified resorcinarenes has been reported but examples are few. ${ }^{[28]}$

\section{Catalytic chemistry with cavitands substituted with $P$ donors}

The first use in transition metal catalysis of a ligand built upon a resorcinarene-cavitand was reported in 2002 by Gibson and Rebek. ${ }^{[29]}$ The authors used the phosphite-oxazoline chelator 1 (Fig. 4) to perform allylic alkylations. Here, the ligand core was an expanded cavitand unit known to bind size- and shape-complementary molecules such as adamantanes.

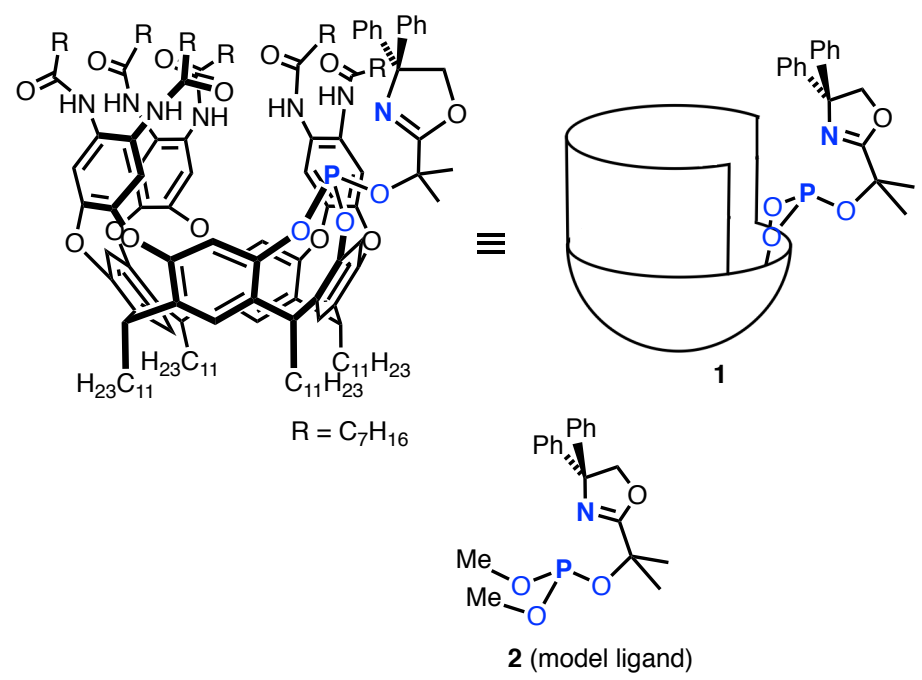

Figure 4. Cavitand phosphite 1 and reference ligand 2

In the presence of palladium(II) and allyl acetate, the ligand produced an allyl palladium $\eta^{3}$ complex, in which the allyl fragment appeared to be oriented towards the cavity axis and within the cavity (Scheme 2). Two ways of coordinating the allylic fragment $\left(\mathrm{H}_{2} \mathrm{C}^{1}-\right.$ $\left.\mathrm{C}^{2} \mathrm{H}=\mathrm{C}^{3} \mathrm{HR}^{\prime}\right)^{-}$are possible, depending on whether the carbon trans to phosphorus is the terminal carbon atom $\mathrm{C}^{1}$ or carbon atom $\mathrm{C}^{3}$ of the allyl ligand. The left pathway in Scheme 2 was expected to dominate as this minimises steric repulsions. 


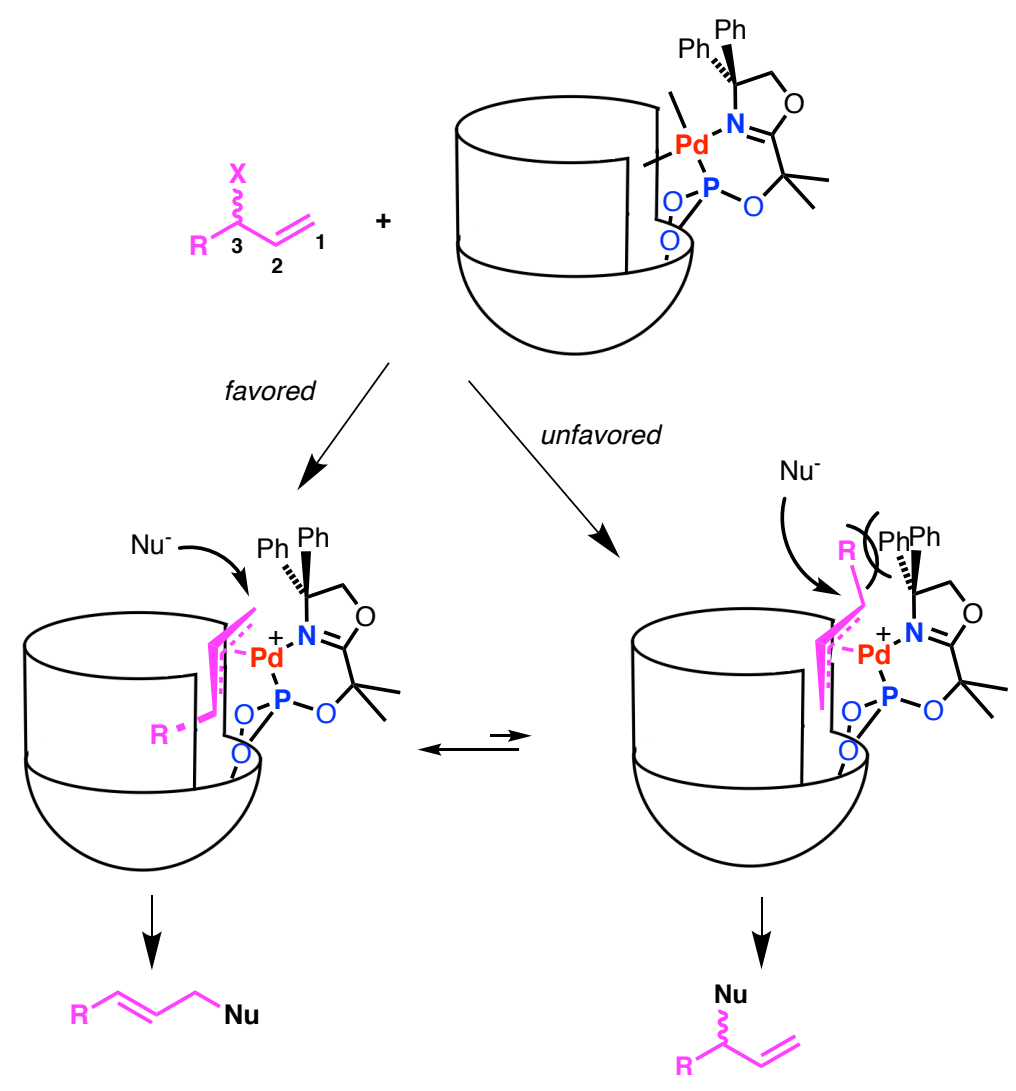

Scheme 2. Nucleophilic attack on the two possible $\eta^{3}$-allyl complexes $\left[\operatorname{Pd}\left(\mathrm{RC}_{3} \mathrm{H}_{4}\right) \cdot \mathbf{1}\right]$. The steric hindrance created by the geminal phenyl groups of the oxazoline moiety favors the left pathway, which results in the linear alkylation product.

Nucleophilic attack by, for example, malonate, was found to occur selectively on carbon $\mathrm{C}(1)$, consistent with the supposed steric effect and electronic factors. The electronic factor influencing the selectivity was considered to be that the $\mathrm{C}$ atom trans to the $\mathrm{P}$ atom, which has a stronger trans influence than $\mathrm{N}$, is more electrophilic. Note that the reference ligand $\mathbf{2}^{[29]}$ displayed the same selectivity for a linear product.

The reaction rate was found to depend on the substrate (substrates tested: $\mathbf{S}_{\mathbf{a}}-\mathbf{S}_{\mathbf{e}}$, Table 1). For example, the conversion of substrates $\mathbf{S}_{\mathbf{b}}$ and $\mathbf{S}_{\mathbf{c}}$ was complete after 2 days, while that of the bulkier substrates $\mathbf{S}_{\mathbf{d}}$ and $\mathbf{S}_{\mathbf{e}}$ was approximately four times lower (Table 1). Remarkably, the smallest substrate $\mathbf{S}_{\mathbf{a}}$ exhibited the lowest reaction rate. Careful examination of competitive experiments (conducted by mixing pairs of substrates) relying on MS analyses revealed that the allylic complexes formed by oxidative addition were more rapidly formed with substrate $\mathbf{S}_{\mathbf{a}}$ (bearing a secondary homoallylic $\mathrm{C}$ atom) than with $\mathbf{S}_{\mathbf{b}}$ (tertiary homoallylic atom), the latter more rapidly than $\mathbf{S}_{\mathbf{c}}$ (quaternary homoallylic atom). The rate of the oxidative addition (i.e. formation of the allyl-Pd complex) varied in the order $\mathrm{R}^{\prime}={ }^{\mathrm{t}} \mathrm{Bu}>{ }^{\mathrm{i}} \mathrm{Pr}>>{ }^{\mathrm{i}} \mathrm{Bu}$. However, as mentioned before, the reactivity of the complexes in the presence of malonate followed a different order. Once the $\mathbf{S}_{\mathbf{a}}$-complex formed, for example, the reaction was inhibited. 
Table 1. Allylic alkylation of substrates $S_{\mathrm{a}-\mathrm{e}}$ using ligands $\mathbf{1}$ and 2. ${ }^{[\mathrm{a}]}$

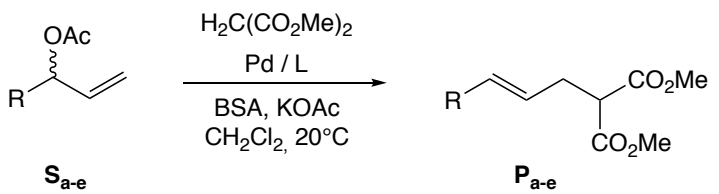

\begin{tabular}{|c|c|c|c|c|c|}
\hline \multirow{2}{*}{ Substrate } & & \multicolumn{2}{|c|}{ Ligand 1} & \multicolumn{2}{|c|}{ Ligand 2} \\
\hline & & Reaction time & Yield (\%) & Reaction time & Yield (\%) \\
\hline & $\mathbf{S}_{\mathbf{a}}$ & $6 \mathrm{~d}^{[\mathrm{b}]}$ & 38 & $2 \mathrm{~h}$ & 85 \\
\hline & $\mathbf{S}_{\mathbf{b}}$ & $2 d$ & 76 & $2 \mathrm{~h}$ & 91 \\
\hline & $\mathbf{S}_{\mathbf{c}}$ & $2 d$ & 96 & $2 \mathrm{~h}$ & 81 \\
\hline & $\mathbf{S}_{\mathrm{d}}$ & $6 \mathrm{~d}^{[\mathrm{b}]}$ & 74 & $2 \mathrm{~h}$ & 78 \\
\hline & $\mathbf{S}_{\mathbf{e}}$ & $6 \mathrm{~d}^{[\mathrm{b}]}$ & 60 & $2 \mathrm{~h}$ & 82 \\
\hline
\end{tabular}

For the substrates $\mathbf{S}_{\mathrm{b}}, \mathbf{S}_{\mathrm{d}}$, and $\mathbf{S}_{\mathrm{e}}$, all of which have a tertiary carbon atom in the homoallylic position, pairwise comparison of these substrates using $\mathrm{Pd}(\mathrm{II})$ and reference ligand 2 showed no significant difference in reaction rates for either the oxidative addition or the overall reaction. The ability of the palladium catalyst formed with $\mathbf{1}$ to stabilise the transition state of the oxidative addition decreased in the order cyclohexyl $>$ iso-propyl $>1$ ethylpentyl. This substrate specificity strongly correlated with the selectivity in product formation $\left(\mathbf{P}_{\mathrm{b}}, \mathbf{P}_{\mathbf{d}}, \mathbf{P}_{\mathbf{e}}\right)$. Thus, the observed selectivities appear to be a direct consequence of the molecular recognition properties of the cavity and underscore the potential of cavitandcontaining catalysts in organic synthesis.

The catalytic efficiency of cavitand-based phosphines is not necessarily related to the receptor or confining properties of the cavity. Thus, it was found that cavitand phosphine 3 having its $\mathrm{P}$ atom separated from the cavity by a methylene group resulted, in the presence of $\mathrm{Pd}(\mathrm{II})$, in a fast Suzuki-Miyaura (SM) cross-coupling catalyst. ${ }^{[30]}$ The reaction rates were found to be 5-7 times faster than that those observed with $\mathrm{PPh}_{3}$. A possible explanation is that during the catalytic process intermediates are formed in which one of the $\mathrm{O}$ atoms close to the $\mathrm{P}$ forms with this atom a chelate ring. This could stabilise monophosphine complexes in the same manner as do Buchwald phosphines, and incidently favour the oxidative addition step. An argument for this interpretation, which thus would exclude a supramolecular effect, is that 
the cavity-free anisole phosphine 4 showed activities comparable to those of the cavitand phosphine. When repeating the experiments with benzyldiphenylphosphine, the activity dropped by ca. $50 \%$.

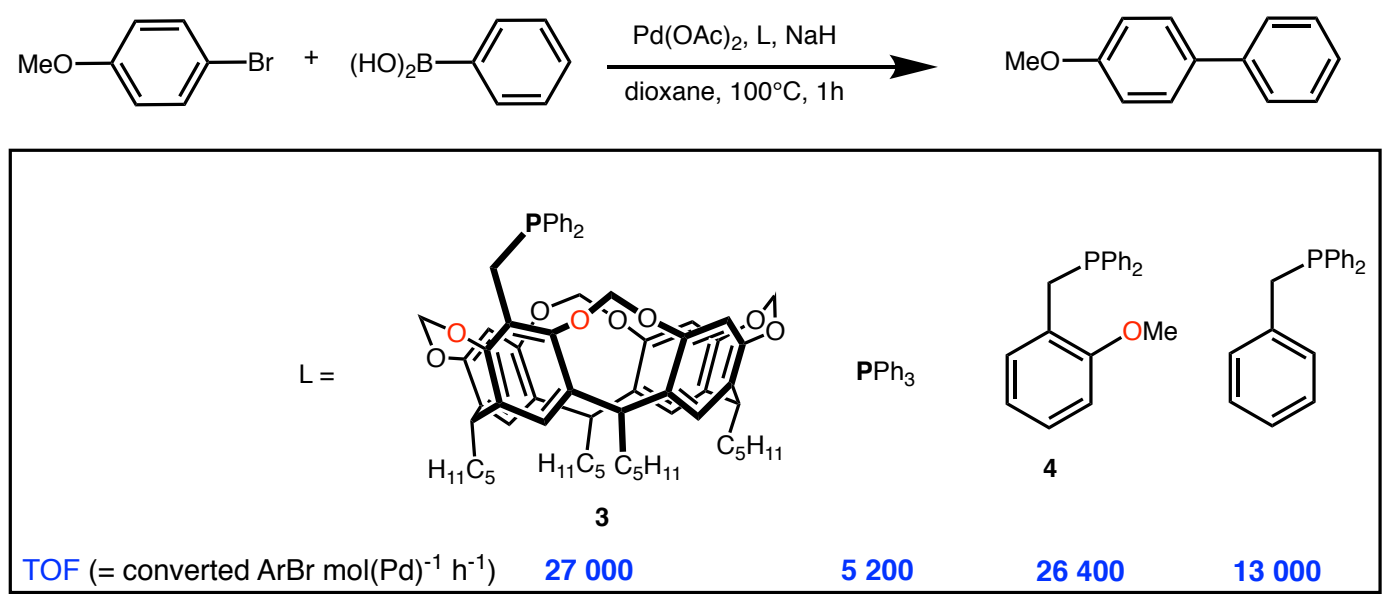

Scheme 3. Suzuki-Miyaura cross-coupling catalysis by cavitand-phosphine $\mathbf{3}$ and three cavity-free phosphines

Diphosphines 5 and 6 (Fig. 5) were tested in the coupling of 4-bromotoluene with $\mathrm{PhB}(\mathrm{OH})_{2}$ and were shown to be more effective than monophosphine 3. Their higher performance was attributed to the formation of complexes with PMP angles larger than $90^{\circ}$, these resulting either from steric repulsions occuring in cyclic oligomeric intermediates (which may form with ligand 5) or arising from the formation of strained chelate complexes (which may form with ligand 6). Larger PMP angles are known to favour the final reductive elimination step of the catalytic process. ${ }^{[30]}$

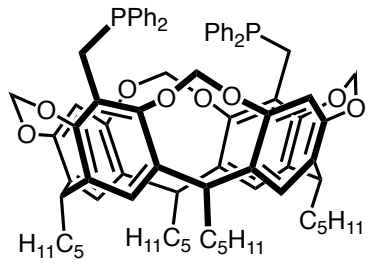

5

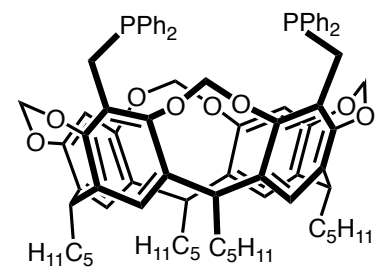

6

Figure 5. Cavitand diphosphines 5 (distally difunctionalised) and $\mathbf{6}$ (proximally difunctionalised)

The first tetraphosphine built upon a cavitand (7) was reported in 2009 (Scheme 4). ${ }^{[31]}$ Complexation studies coupled with MS measurements revealed that each pair of adjacent phosphine arms of this ligand may function as a chelating unit. The authors showed that in the presence of $\left[\mathrm{Pd}(\mathrm{OAc})_{2}\right]$ and a base, ligand 7 is active in Heck coupling reactions (Scheme 4). The catalytic results indicated that the rate of the reaction had a maximal value when only one equivalent of cavitand was added to the palladium, any excess of 7 drastically decreasing the yield. This finding together with ${ }^{31} \mathrm{P}$ NMR investigations indicated that the presence of free phosphane units is required for stabilisation and/or generation of the catalytically active species. The activities themselves were not unusual when compared with that of $\mathrm{PPh}_{3}$. Disappointingly, the presence, after complexation, of four phosphine ligands near the metal 
centre did not markedly accelerate the reaction, unlike the observations made by Santelli for similar reactions with another tetraphosphine, cis,cis,cis-1,2,3,4-tetrakis(diphenylphos phinomethyl)cyctopentane (TEDICYP), in which motions of the $\mathrm{P}$ atoms are more restricted. ${ }^{[32]}$

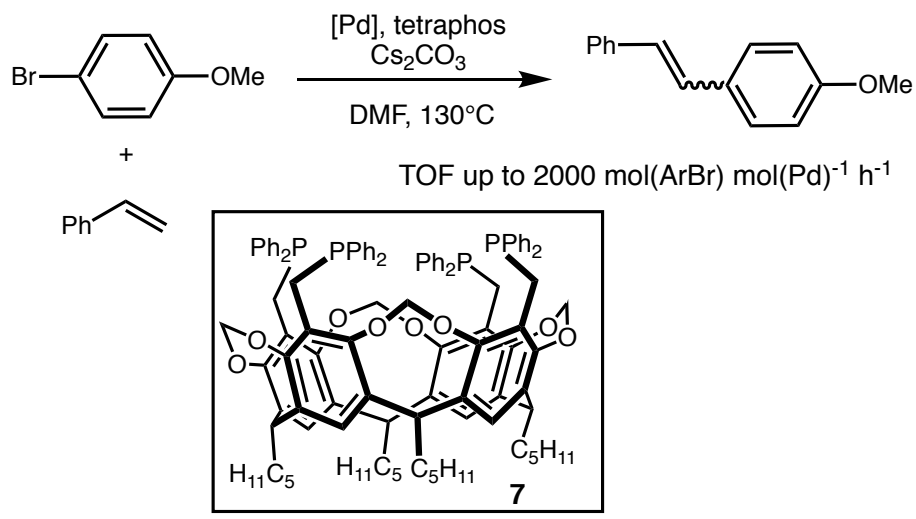

Scheme 4. Heck reaction with tetraphosphine 7

A structural study combined with molecular modelling revealed that monophosphine 8 (Fig. 6), a cavitand with a $\mathrm{P}$ atom directly attached to the upper rim of the bowl, behaves as a ligand with variable bulk, its encumbrance depending on the orientation of the $\mathrm{P}$ lone pair. ${ }^{[33]}$ Thus, when the $\mathrm{P}$ atom points towards the cavitand axis, its cone angle is by ca. $45^{\circ}$ greater than if it points towards the exterior of the cavity. Consistent with its strong crowding, ligand 8, when combined with $\left[\mathrm{Pd}(\mathrm{OAc})_{2}\right]$, provided an efficient catalyst for the coupling of a variety of aryl boronic acids with aryl chlorides. Depending on the substrates used, the catalytic system was found to be 3-7 times more active than $\mathrm{PPh}_{3}$ (study carried out with aryl bromides, see Table 2). Comparison with bulkier triarylphosphines as well as phosphines 9 and 10, bearing respectively one and two $o$-MeO groups on one of their aryl substituents - all leading to higher activities -, suggested that the high catalytic activity of 8

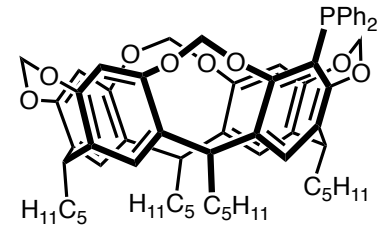

8<smiles>COc1ccccc1P(O)c1ccccc1</smiles>

9<smiles>COc1cccc(OC)c1P</smiles>

10

Figure 6. Cavitand-phosphine $\mathbf{8}$ and cavity-devoid ligands $\mathbf{9}$ and $\mathbf{1 0}$

arose from a combination of two features, namely (i) its ability to form $P, O$ chelate complexes, this making the metal environment sterically more crowded and the metal more 
Table 2. Suzuki-Miyaura cross-coupling of aryl bromides catalyzed by $\left[\mathrm{Pd}(\mathrm{OAc})_{2}\right] /$ triarylphosphines. $^{[\mathrm{a}]}$

\begin{tabular}{lcccc} 
Entry & \multicolumn{5}{c}{ Triarylphosphine, \% conversion } \\
& $\mathrm{PPh}_{3}$ & $\mathbf{9}$ & $\mathbf{1 0}$ & $\mathbf{8}$ \\
\hline $\mathrm{Br}$ & 8.1 & 18.3 & 22.6 & 25.1 \\
\hline $\mathrm{Br}$ & 6.5 & 5.4 & 7.1 & 16.1 \\
\hline $\mathrm{Br}$ & 7.0 & 14.8 & 17.3 & 26.6 \\
\hline
\end{tabular}

[a] $\left[\mathrm{Pd}(\mathrm{OAc})_{2}\right]\left(5 \times 10^{-7} \mathrm{mmol}, 1 \times 10^{-4} \mathrm{~mol} \%\right)$, phosphine $\left(1 \times 10^{-6} \mathrm{mmol}, 2 \times 10^{-4} \mathrm{~mol} \%\right)$, $\mathrm{ArBr}(0.5 \mathrm{mmol}), \mathrm{PhB}(\mathrm{OH})_{2}(1 \mathrm{mmol}), \mathrm{NaH}(60 \%$ dispersion in mineral oil; $1 \mathrm{mmol}), 1,4-$ dioxane $(1.5 \mathrm{~mL})$, decane $(0.050 \mathrm{~mL}), 100^{\circ} \mathrm{C}, 1 \mathrm{~h}$. The conversions were determined by $\mathrm{GC}$, the calibrations being based on decane.

electron-rich, and (ii) its increased bulkiness when the P lone pair points towards the cavitand axis, this favouring the formation of monoligated intermediates. However, care must be taken with the interpretation that $P, O$ chelation increases the activity, as it was recently found that when the metal centre bears a positive charge (which is not the case here), $P, O$ chelation may result in cavitand cleavage with formation of a phosphino-enolato metal complex, ${ }^{[34]}$ this being inactive in cross coupling. Note that nickel complexes of this type were found active in ethylene oligomerisation.

The design of coordination complexes (excluding complexes resulting from a reversible, supramolecular self-assembly process) that allow metal-catalysed reactions to take place inside a restricted space (bowl, clip, capsule) with the aim of controlling activity and selectivity are currently attracting the attention of several research groups. ${ }^{[29,35]}$ In the particular field of resorcinarene chemistry, Iwasawa et al. have used the digold complexes $\mathbf{1 1}$ and 12 (Figure 7), both based on a cavity flanked by aromatic rings, in the catalytic crossdimerisation of terminal alkynes. ${ }^{[19]}$ For example, the reaction of ethynylbenzene with 1octyne in the presence of a mixture of $11(1 \mathrm{~mol} \%)$ and 2 equiv. of AgOTf gave after $20 \mathrm{~h}$ (rt) cross adduct $14(58 \%)$ and homoadduct 15 with a 14/15 ratio of 3.0:1 (Scheme 5, top). With the less expanded cavity 12 the yield of 14 dropped to $6 \%$ with a 14/15 ratio of $4.3: 1$, while model compound $\mathbf{1 3}$ did not catalyse the reaction at all. The authors also investigated the homodimerisation of 1-octyne, leading to $\mathbf{1 6}$ and its isomer iso-16 (Scheme 5, bottom) The bis-quinoxaline-bridged complex 11 gave 16 selectively in $63 \%$ yield. In contrast, with bis-pyrazine 12, the yield of $\mathbf{1 6}$ droped to $18 \%$, and the formation of small amounts of iso-16 was observed (16:iso-16 = 97:3). With the non-walled cavitand 13, only trace amounts of coupling adducts were observed. Overall, these studies illustrate the superiority of quinoxaline-expanded cavitand 11 over that of 12 and 13 in the catalytic dimerisation of terminal alkynes. The authors proposed that the catalysis with $\mathbf{1 1}$ occurred in a supramolecular 


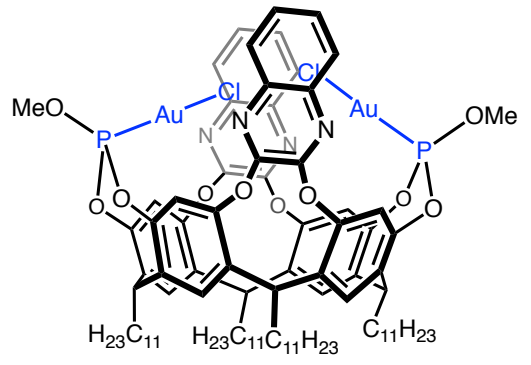

11

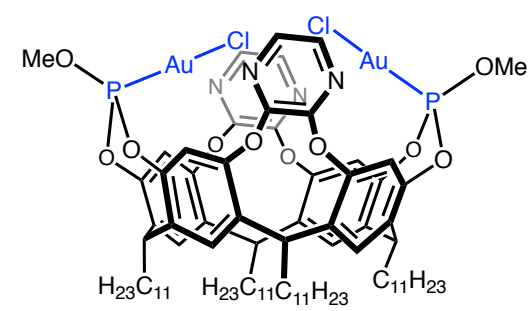

12

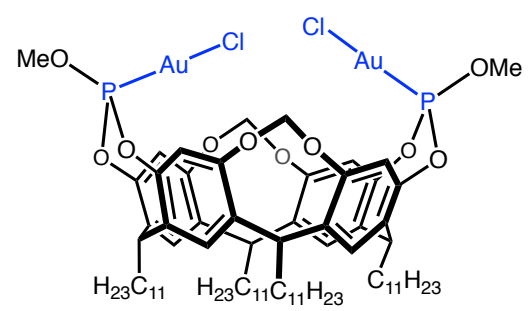

13

Figure 7. Digold complexes based on resorcinarene cavitands

manner, the quinoxaline parts providing a stronger $\pi$-cloud than that found in the interior of 11 and 12, thereby strongly enhancing the interaction of the two alkyne partners. The confinement created by $\mathbf{1 1}$ further limits the number of transition-state geometries, this possibly being at the origin of the slightly higher selectivity found with $11 \mathrm{vs.12}$. The authors also showed that the presence of two introverted $\mathrm{Au}$ atoms is quintessential for catalysis. ${ }^{[36]}$ Similar results were obtained with analogues of $\mathbf{1 1}$ having $\mathrm{NMe}_{2}$ instead of OMe substituents on phosphorus. ${ }^{[37]}$ 


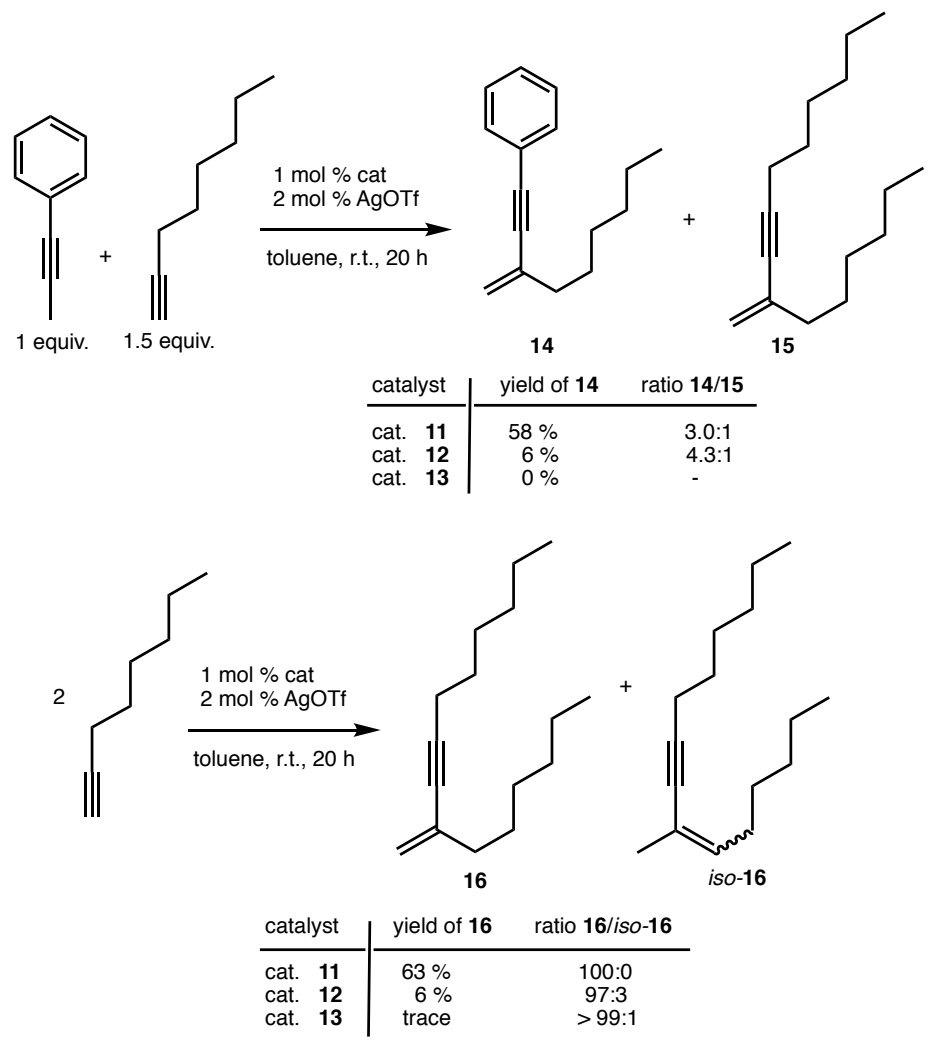

Scheme 5. Catalytic reactions involving terminal alkynes with digold catalysts 11-13

The same research team also synthesised cavitands 17-19, all equipped with three quinoxaline walls and bearing a single, inwardly directed P-Au unit (Scheme 6) ${ }^{[38]}$ Complex 17 turned out to be efficient in the catalytic hydration of 9-ethynylanthracene (Scheme 6). All three complexes also catalysed a Conia-ene reaction of the $\beta$-keto ester alkyne 20 (Scheme 6). The main conclusion of these investigations was that the top of the catalytic site of these complexes remains open so that guests can sample the space, enter and leave, and thus these complexes may efficiently operate as catalysts.
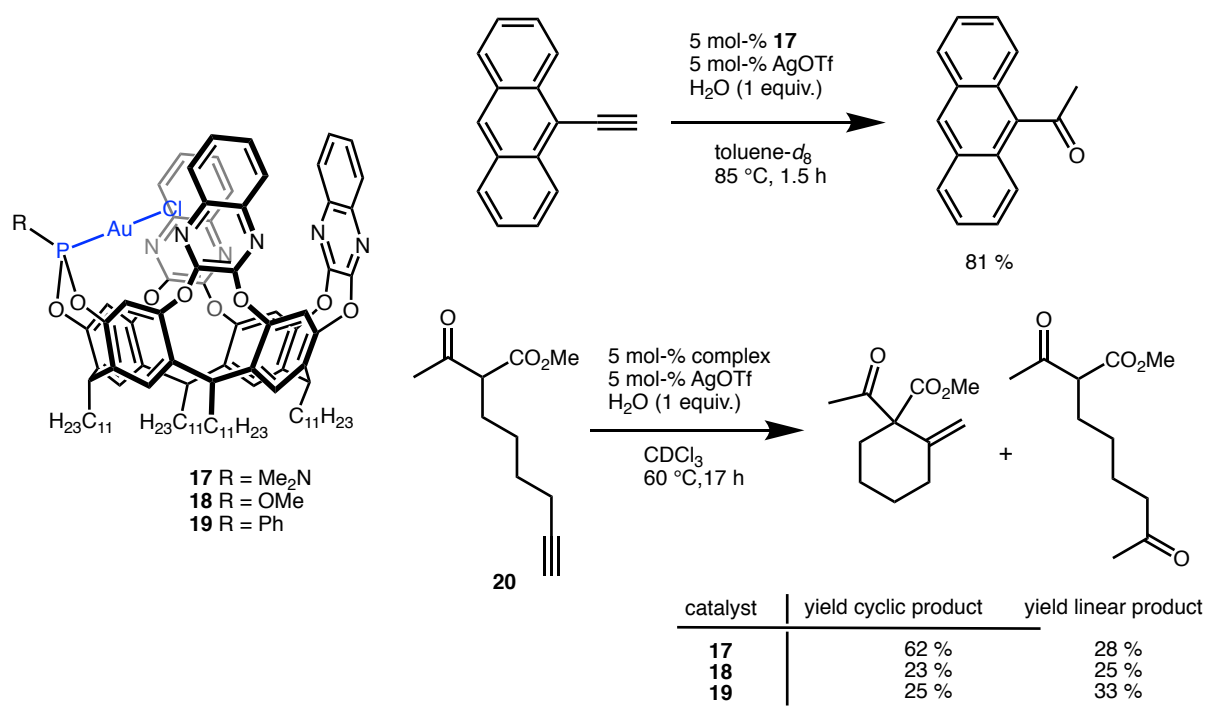

Scheme 6. Catalytic reactions carried out with the bowl-shaped monogold complexes 17-19 
The first Buchwald-type biarylphosphine based on a cavitand, 21, was reported by Elaieb et al. (Fig. 8). This ligand displayed activities in SM coupling of bulky aryl chlorides with sterically hindered arylboronic acids that were ca. $40 \%$ higher than those of the Buchwald analogue S-Phos (22), which is devoid of a cavity. Its better performance has been attributed to the permanent exo-positioning of the metal during catalysis, which enables steric interactions of two pentyl substituents with the second coordination sphere of the metal, this influencing the reductive elimination step (a similar effect was invoked with catalysts derived from 34-36, vide infra).

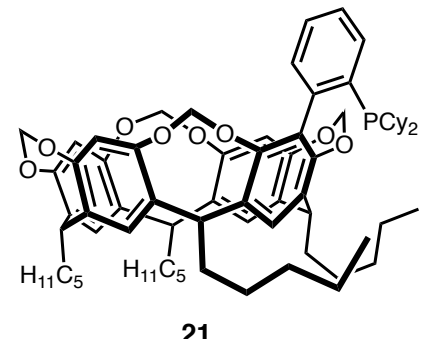

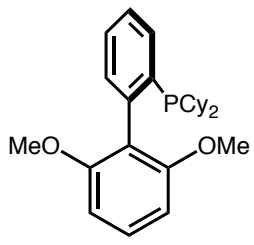

22

Figure 8. Biarylphosphines 21 and 22

Several recent publications have illustrated the manner in which cavitands can be used for the generation of molecular capsules. ${ }^{[39]}$ Capsule synthesis may be realised by covalent construction, ${ }^{[22 \mathrm{~d}]}$ a procedure extensively developed as the basis of carcerand chemistry but, more conveniently, such molecules can also be generated by self-assembly processes, these involving either metal complexation, ${ }^{[22 \mathrm{c}, 40]}$ hydrogen bonding ${ }^{[41]}$ or van der Waals interactions. ${ }^{[42]}$ Many of the reported cages have been shown suitable for hosting large guests. An example of capsule formation through metal chelation and which does not involve a selfassembly process, is provided in the use of a diphosphine built on a backbone consisting of two covalently linked cavitands (23). ${ }^{[43]}$ Reaction of 23 with $\left[\mathrm{PtCl}_{2}(\mathrm{PhCN})_{2}\right]$ under high dilution afforded the metallo-capsules cis-24 and trans-24 (Scheme 7). The former was used succesfully in combination with $\mathrm{SnCl}_{2}$ for the hydroformylation of styrene. The activity and selectivity (Table 3 ) of the system 

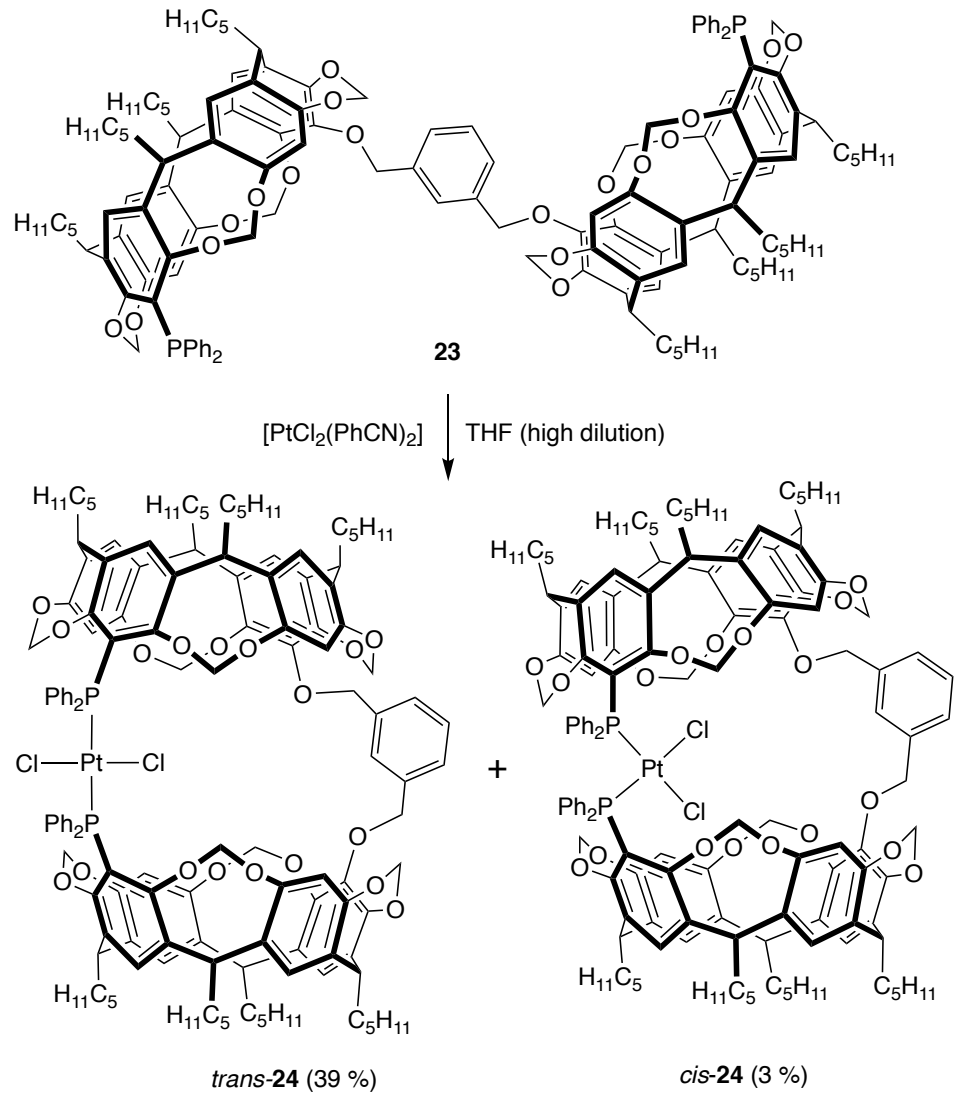

Scheme 7. Formation of metallocapsules from diphosphine $\mathbf{2 3}$

towards the branched aldehyde were both significantly superior to those observed for the reference complex trans $-\mathrm{PtCl}_{2} \mathrm{~L}_{2}$, in which $\mathrm{L}$ is the monophosphane-monocavitand 8 , as well as $\mathrm{PPh}_{3}$. The increased activity of the capsular complex may reflect the initial formation of a hydrido intermediate with a somewhat distorted trigonal-bipyramidal structure that facilitates the intracapsular olefin/PtH insertion step. The observed aldehyde selectivity can be understood as a consequence of the shape of the capsule, which is sterically better suited for hosting a branched Pt-alkyl unit than a linear one (Scheme 8). The catalytic outcome with trans-24 was similar obtained with trans-[ $\left.\mathrm{PtCl}\left(\mathrm{SnCl}_{3}\right)(23)\right]$ (run performed without additional $\mathrm{SnCl}_{2}$ ).

Table 3. Hydroformylation of styrene with cis-24/ $\mathrm{SnCl}_{2}$

\begin{tabular}{cccccc}
\hline \multirow{2}{*}{ Entry } & Platinum complex & $\begin{array}{c}\text { Time } \\
\text { (h) }\end{array}$ & Conversion (\%) & $\begin{array}{c}\text { Aldehydes distribution } \\
\text { Linear (\%) }\end{array}$ & Branched (\%) \\
\hline 1 & trans-24 & 24 & 55 & 36 & 64 \\
2 & trans $-\left[\mathrm{PtCl}_{2}(\mathbf{8})_{2}\right]$ & 24 & 15 & 46 & 54 \\
3 & trans $-\left[\mathrm{PtCl}_{2}\left(\mathrm{PPh}_{3}\right)_{2}\right]$ & 24 & 40 & 53 & 47 \\
4 & trans $-\left[\mathrm{PtCl}\left(\mathrm{SnCl}_{3}\right)(\mathbf{2 3})\right]$ & 16 & 60 & 38 & 62
\end{tabular}

General conditions: [Pt] (1 mol \%), $\mathrm{SnCl}_{2}(2 \mathrm{~mol} \%$; except for entry 4: $0 \%)$, styrene (1 $\mathrm{mmol}), \mathrm{P}\left(\mathrm{CO} / \mathrm{H}_{2}\right)=45$ bar, $\mathrm{T}=100^{\circ} \mathrm{C}$, toluene $(5 \mathrm{~mL})$. The conversions were determined by ${ }^{1} \mathrm{H}$ NMR spectroscopy. 


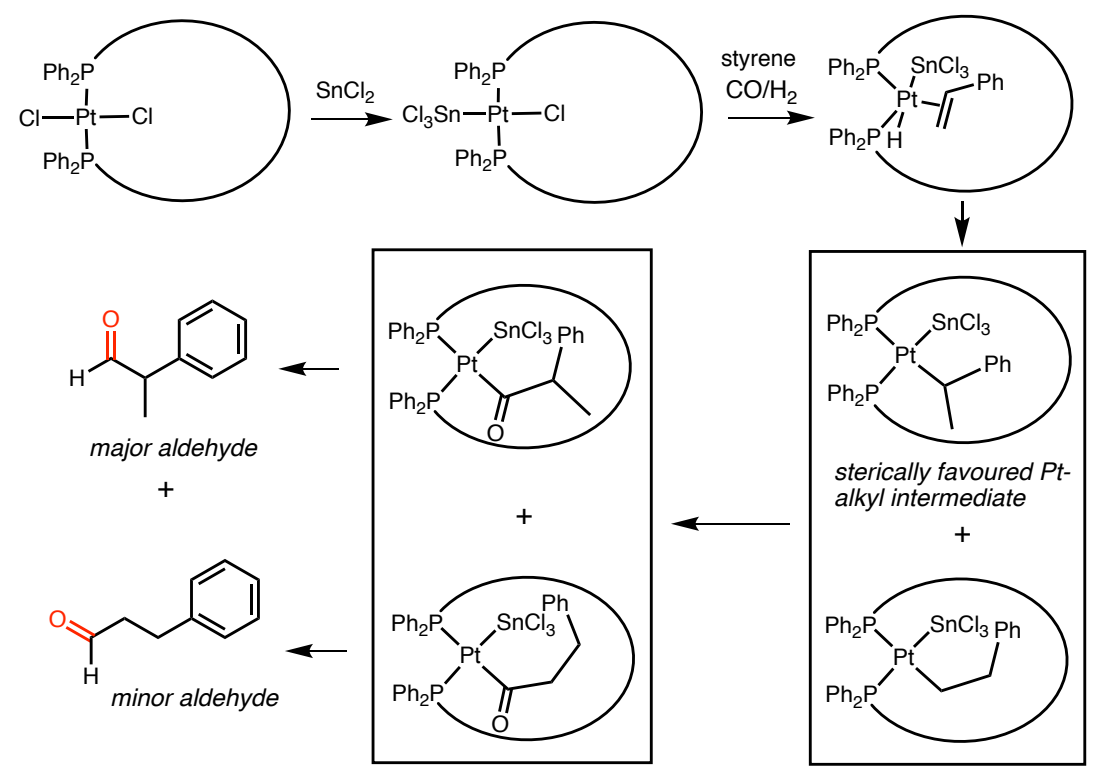

Scheme 8. Styrene hydroformylation with trans $-\mathbf{2 4} / \mathrm{SnCl}_{2}$

\section{Catalytic chemistry with cavitands bearing $N$-heterocyclic carbene (NHC) units}

El Moll et al. have described the synthesis of the imidazolium salts 23-33 (Fig. 9). ${ }^{\text {[44] }}$ These are procarbenes which were assessed in Suzuki-Miyaura cross-coupling between phenyl boronic acid and several aryl bromides. Note that before this study imidazolium salts built on a resorcinarene skeleton had already been reported, but their use was restricted to molecular recognition studies. ${ }^{[45]}$ In combination with $\left[\mathrm{Pd}(\mathrm{OAc})_{2}\right]$ and a base, 23-33 provided efficient Suzuki-Miyaura catalysts for the cross-coupling of aryl bromides with phenylboronic acid. The highest activity (TOF $=41,600 \mathrm{~mol}(\mathrm{ArBr}) \mathrm{mol}(\mathrm{Pd})^{-1} \mathrm{~h}^{-1}$ ) was observed in the arylation of 1-bromonaphthalene in the presence of the proximallydisubstituted cavitand 28. In fact, only relatively small differences in activity were observed within the three series of imidazolium salts, indicating that they all behave as single-site NHC sources. 


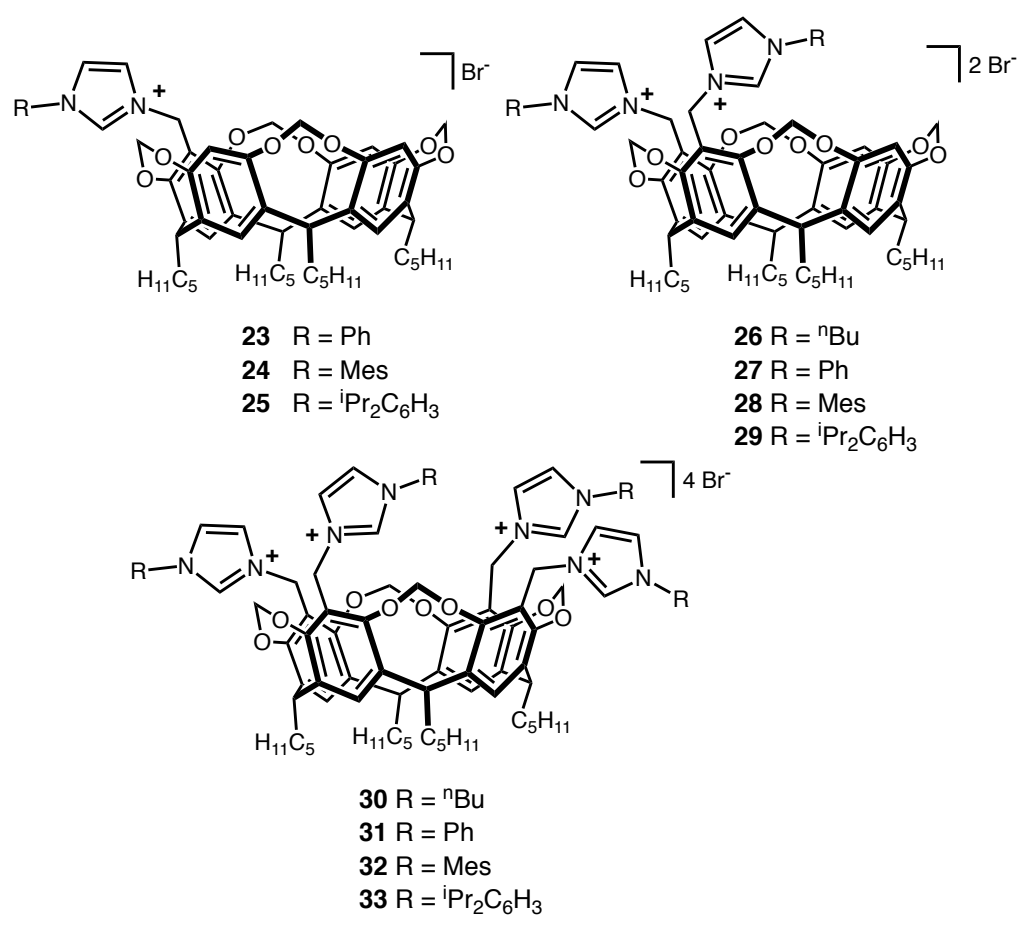

Figure 9. Procarbenes 23-33

Cavitands having an imidazolium ring directly attached through an $\mathrm{N}$ atom to the upper rim of a cavitand (Fig. 10) have also been assessed in coupling reactions. For example, the three imidazolium salts 34-36 were used as catalyst precursors in Suzuki-Miyaura (SM) cross-coupling. ${ }^{[46]}$ In these pro-carbenes, the second $\mathrm{N}$ atom was substituted by an alkyl group ( $\mathrm{R}=\mathrm{n}$-propyl, iso-propyl, benzyl), and the bridging atoms of the resorcinarene unit had pentyl substituents. Optimal catalytic performances were obtained by using an imidazolium/Pd ratio of $1: 1$. The catalytic systems displayed high activities, which increased in the order $\mathrm{R}=n$ propyl (34) < i-propyl (35) < benzyl (36). With 36, activities up to 30,100 mol(converted $\operatorname{ArX}) \operatorname{mol}(\mathrm{Pd})^{-1} \mathrm{~h}^{-1}$ were reached in the arylation of bromotoluene at $100^{\circ} \mathrm{C}$ in dioxane. Comparative studies showed that the performance of $\mathbf{3 6}$ was up to 10 times superior to that of related salts devoid of a cavity-shaped unit (37-39). These experiments illustrate the active role of the cavity core of the ex-36 carbene ligand, the steric encumbrance of which facilitates the reductive elimination step (Figure 11, left part). Modification of the cavitand structure by replacement of the pentyl substituents of $\mathbf{3 6}$ with phenyl groups (leading to 40) resulted in considerably lower activities, this being consistent with steric interactions between the metal centre and two pentyl groups of the ex-36 carbene during catalysis (Figure 11, right part). The fact that the catalytic outcome may be influenced by the nature of the bridge substituents is further evidence that the $\mathrm{Pd}$ catalysts obtained from 34-36 have their metal centre preferentially located outside the cavity.

It is worth mentioning here that SM tests were also performed starting from the isolated PEPPSI-Pd complex 41 ${ }^{[47]}$ (Fig. 12) (PEPPSI $^{[48]}=$ pyridine-enhanced precatalyst preparation stabilization and initiation) as well as related bulky ones, ${ }^{[4]}$ which led to similar conclusions regarding the role played by the flexible pentyl groups at the lower rim. The investigations carried out with $\mathbf{4 1}$ further revealed that this catalyst is very effective in the coupling of aryl chlorides with sterically hindered boronic acids. However, there was no clear indication that the cavity subunit operated as a receptor. 


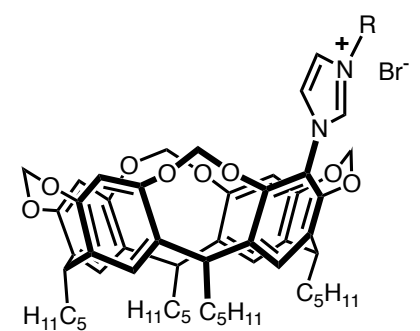<smiles>c1ccc(C[B-](c2ccccc2)c2ccccc2)cc1</smiles>

37 $\begin{array}{ll}34 & R={ }^{n} P r \\ 35 & R= \\ R & ={ }^{\mathrm{P} r}\end{array}$ $36 \quad \mathrm{R}=\mathrm{Bn}$<smiles>COc1cccc(OC)c1-n1cc[n+](Cc2ccccc2)c1</smiles>

39<smiles>COc1ccccc1-n1cc[n+](Cc2ccccc2)c1</smiles>

38

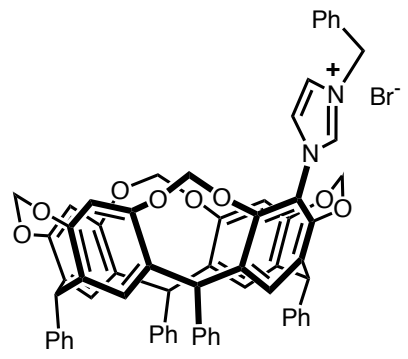

40

Figure 10. Procarbenes 34-40
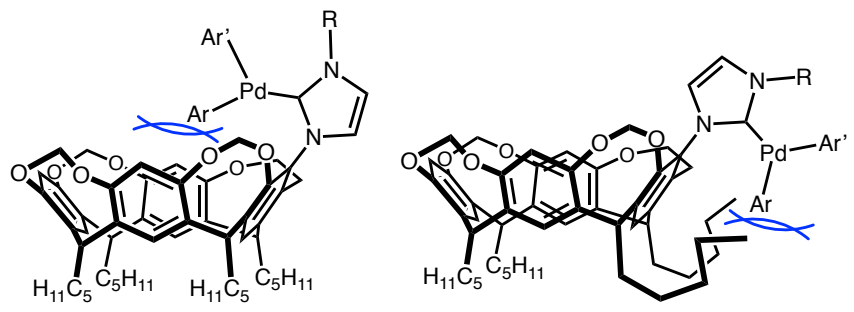

Figure 11. Sites of steric interactions in catalytic intermediates derived from 34-36.

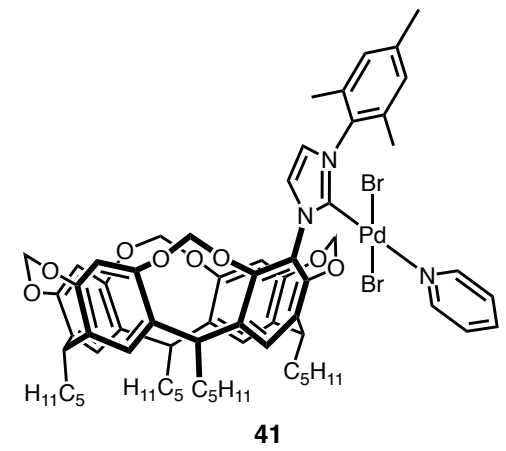

Figure 12. N-heterocyclic carbene complex 41 (PEPPSI-type)

Imidazolium salts 34-36 have been further assessed in Ni-catalysed Kumada-TamaoCorriu cross-coupling of aryl halides with arylmagnesium halides (Scheme 9). ${ }^{[50]}$ Such reactions are generally performed with palladium, but it is highly desirable to conduct these reactions with more cost-efficient catalysts, notably those based on nickel. Actually, the 1:1 combination of 34-36 with $\left[\mathrm{Ni}(\operatorname{cod})_{2}\right](\operatorname{cod}=1,5$-cyclooctadiene) resulted in very efficient systems, the activities of which varied in the same order as above for the SM coupling 
reactions: $\mathrm{R}=n$-propyl (34) isopropyl $(35) \approx$ benzyl (36). A remarkable turnover frequency of $60,400 \operatorname{mol}(\mathrm{ArX}) \operatorname{mol}(\mathrm{Ni})^{-1} \mathrm{~h}^{-1}$ was obtained in the coupling of 2-bromo-6methoxynaphthalene with $\mathrm{PhMgBr}\left(100{ }^{\circ} \mathrm{C}\right.$ in dioxane, with precursor 36) (Scheme 10). The high activities of these cavitands were attributed to steric effects that facilitated the reductiveelimination/product decoordination step. Comparative experiments carried out with the benzyl-bridged resorcinarene $\mathbf{4 0}$, as well as cavity-free imidazolium salts bearing 2methoxyaryl substituents, indicated that the efficiency of the above catalytic systems again was mainly due to steric interactions between the metal and the flexible pentyl substituents attached to the two methine carbon atoms closest to the heterocycle. As usual with nickel, homocoupling products were observed in the above runs, although their proportion did not exceed $13 \%$.

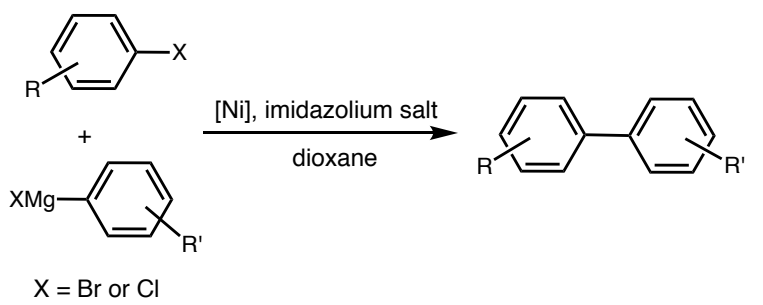

Scheme 9. Kumada-Tamao-Corriu cross-coupling with nickel

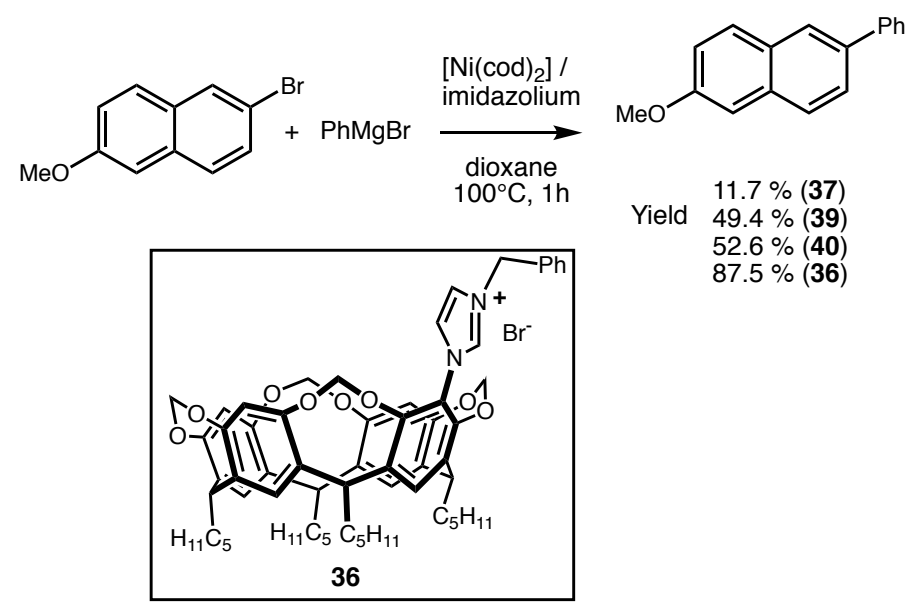

Scheme 10. Ni-catalysed coupling of 2-bromo-6-methoxynaphthalene with $\mathrm{PhMgBr}$ using procarbenes $36,37,39$, and 40

Allylic substitution with organo-copper compounds has recently emerged as a method which usefully complements the palladium-catalysed version of this reaction. The main advantage of copper over palladium, besides its lower price, is that it generally allows the reaction to occur with $\mathrm{S}_{\mathrm{N}} 2$ ' selectivity, i.e. to favour the $\gamma$-product over the $\alpha$ one (Scheme 11). This in turn is relevant to the synthesis of chiral compounds. The procarbene salts $\mathbf{3 6}$ and 42-46, all having one of their nitrogen atoms substituted by a 2,8,14,20tetrapentylresorcinarenyl (TPR) group, were tested in situ in the copper-catalysed arylation of cinnamyl bromide with arylmagnesium halides. ${ }^{[51]}$ The catalytic systems produced mixtures of linear (l) and branched (b) arylation compounds in variable proportions, the highest $b / 1$ ratio (78:22) being observed 


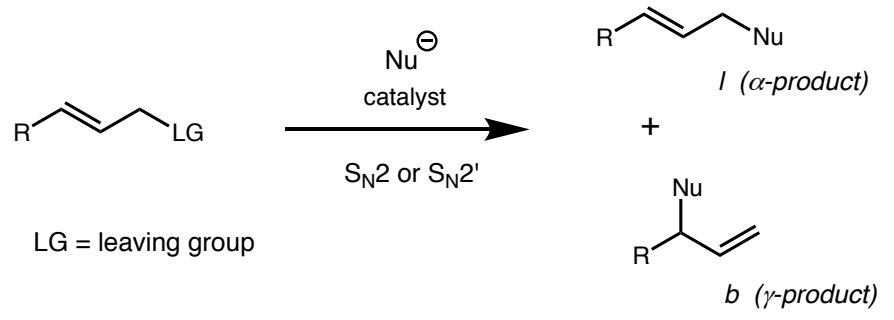

Scheme 11. Allylic substitution

for the crowded imidazolium salt 44 (in which the second nitrogen atom bears a bulky mesityl group). Although bulky substituents are expected to favour the reductive elimination step leading to the $\gamma$-product, ${ }^{[51]}$ the bulky TPR group had only a small influence on the selectivity (Figure 13). The authors proposed that it would make sense to modify the catalyst

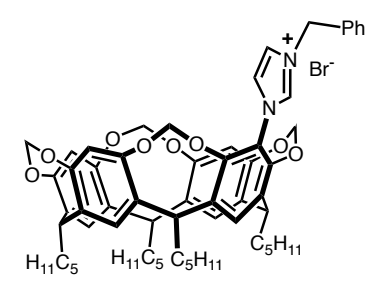

$36 \mathrm{~b} / \mathrm{l}=22: 78$

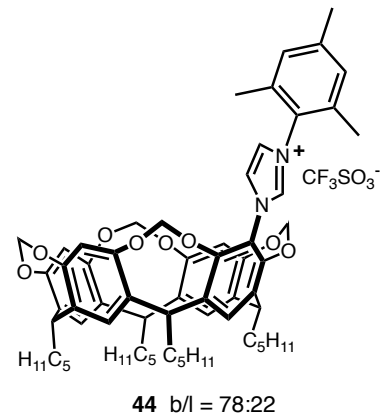

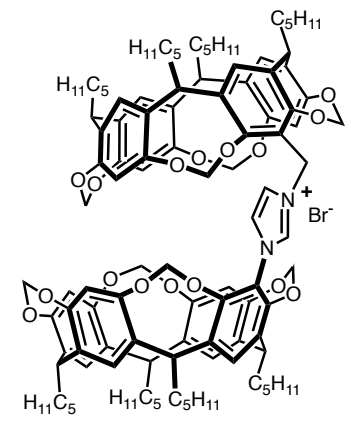

$42 \mathrm{~b} / \mathrm{l}=31: 69$

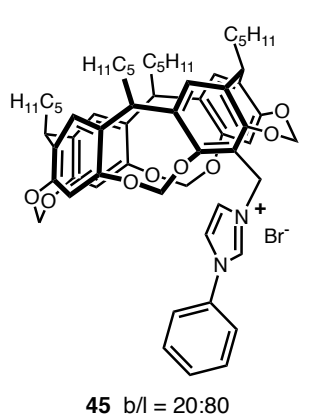

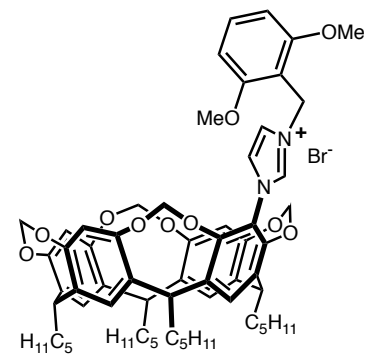

$43 \mathrm{~b} / \mathrm{l}=47: 53$

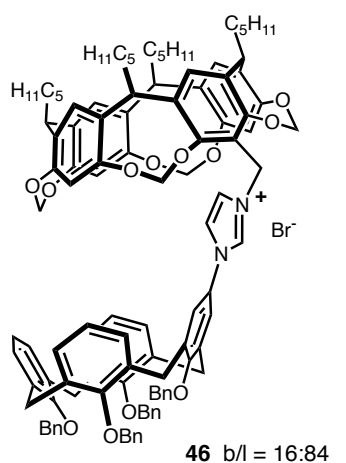

Figure 13. Branched/linear aldehyde ratios obtained in the copper-catalysed allylic alkylation of cinnamyl bromide and phenyl magnesium bromide with salts 36 and 42-46 (Reaction conditions: $\left[\mathrm{Cu}(\mathrm{OTf})_{2}\right](1 \mathrm{~mol}-\%)$, imidazolium salt (1 mol-\%), $\mathrm{PhCH}=\mathrm{CHCH}_{2} \mathrm{Br}(0.32$ $\left.\mathrm{mmol}), \mathrm{PhMgX}(0.39 \mathrm{mmol}), \mathrm{Et}_{2} \mathrm{O}(3 \mathrm{~mL}),-78{ }^{\circ} \mathrm{C}, 1 \mathrm{~h}\right)$

structure so as to force the metal centre to remain located permanently above the cavitand entrance (rather than being pushed towards its exterior), markedly augmenting the ligand bulk. Finally, it should be mentioned that starting from an isolated [ $\mathrm{CuBr}(\mathrm{NHC})]$ complex instead of using an imidazolium/ $\mathrm{Cu}(\mathrm{OTf})_{2}$ mixture for the catalytic runs did not significantly modify the catalytic outcome. ${ }^{[51]}$

\section{Catalysis using cavitands substituted with nitrogen donors}


Cavitands substituted with groups that contain a nitrogen donor atom have been little used in catalysis. Chavagnan et al. have prepared the bis-iminophosphorane 47. ${ }^{[52]}$ Molecular modeling revealed that because of the large N...N separation, 47 cannot act as a chelating ligand. A 1:1 mixture of 47 and $\left[\mathrm{Rh}(\mathrm{COD})_{2}\right] \mathrm{BF}_{4}$ was used as a catalytic system for the competitive hydrogenation of 1:1 mixtures of terminal olefins (Table 4). A remarkable substrate-selectivity factor of 39.2 in favour of the linear olefin was observed after $1 \mathrm{~h}$ in the reduction of a hex-1-ene / 3-ethyl-pent-1-ene mixture. After $8 \mathrm{~h}$, the selectivity was still as high as 4.1. Carrying out the test with hex-1-ene and dec-1-ene gave selectivity factors of 5.4 and 1.6 respectively after $1 \mathrm{~h}$ and $8 \mathrm{~h}$. The substrate selectivity was considerably lower with a mixture of olefins of similar size, such as styrene and 3-ethyl-pent-1-ene (Table 4).

Table 4. Competitive hydrogenation of $\alpha$-olefins catalysed by the $\left[\mathrm{Rh}(\operatorname{cod})_{2}\right] \mathrm{BF}_{4} / 47$ system.

\begin{tabular}{|c|c|c|c|c|}
\hline Entry & $\mathrm{R}^{1} \mathrm{CH}=\mathrm{CH}_{2}$ & $\mathrm{R}^{2} \mathrm{CH}=\mathrm{CH}_{2}$ & Time $(\mathrm{h})$ & $\begin{array}{l}\text { Hydrogenated products (\%) } \\
\qquad \mathrm{R}^{1} \mathrm{CH}_{2} \mathrm{CH}_{3} / \mathrm{R}^{2} \mathrm{CH}_{2} \mathrm{CH}_{3}\end{array}$ \\
\hline 1 & & & 1 & $19.6 / 0.5=39.2$ \\
\hline 2 & & & 5 & $62.6 / 8.4=7.4$ \\
\hline 3 & & & 8 & $84.6 / 20.4=4.1$ \\
\hline 4 & & & 1 & $13.5 / 2.5=5.4$ \\
\hline 5 & & & 5 & $48.1 / 10.2=4.7$ \\
\hline 6 & & & 8 & $77.4 / 47.8=1.6$ \\
\hline 7 & & & 5 & $36.2 / 15.0=2.4$ \\
\hline 8 & & & 8 & $58.2 / 29.0=2.0$ \\
\hline
\end{tabular}

Conditions: $\left[\mathrm{Rh}(\mathrm{cod})_{2}\right] \mathrm{BF}_{4}(1 \mathrm{~mol} \%), 47$ (1 mol \%), olefins (1.0 mmol of each), $\mathrm{P}\left(\mathrm{H}_{2}\right)=5$ bar, THF ( $5 \mathrm{~mL})$, r.t. The conversions were determined by GC.

Olefin discrimination also occurred with the glucosidic substrate 48 (Scheme 12) which contains two $\mathrm{C}=\mathrm{C}$ double bonds in different steric environments. When the reaction with 48 was conducted with a $\mathrm{H}_{2}$ pressure of 5 bar and with 2 mol- $\%$ of the catalyst, product 49 , in which only the allylic double bond had been hydrogenated, was formed exclusively in $84 \%$ yield after $14 \mathrm{~h}$.

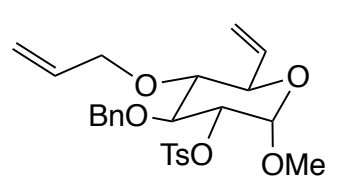

48

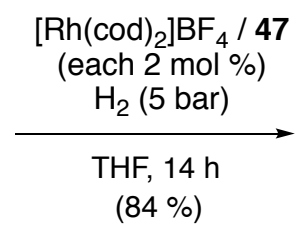

(84\%)

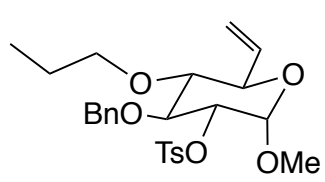

49

Scheme 12. Diolefin hydrogenation leading to $\mathbf{4 9}$

By carrying out comparative studies with the iminophosphoranes 49, 50-52 (Table 5) the authors came to the conclusion that substrate discrimination is only observed if: a) two iminophosphorane units are available per Rh centre; b) the nitrogen atoms are substituted with an aryl ring that bears a methoxy group; and c) the two iminophosphorane units are tethered to the same resorcinarene platform. Consistent with these observations, they concluded that 
both iminophosphorane moieties of $\mathbf{4 7}$ are involved in the catalytic process. Owing to the large $\mathrm{N} \cdots \mathrm{N}$ separation, this cannot occur via catalytic intermediates containing an $\mathrm{N}, \mathrm{N}$ chelated rhodium centre. Instead, one of the two nitrogen atoms and a methoxy group of the other anisyl-iminophosphorane moiety must form a chelating $N, O$ unit that spans the wider face of the cavitand. This would locate the rhodium centre above the main entry to the cavity and orientate two free coordination sites towards the cavity interior (Figure 14). The observed substrate selectivity can then be seen as due to a shape selective process controlled by the cavity size.

Table 5. Competitive hydrogenation of $\alpha$-olefins, influence of the ligand. ${ }^{[\mathrm{a}]}$

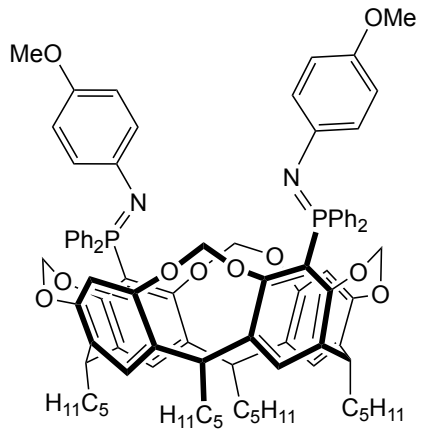

47

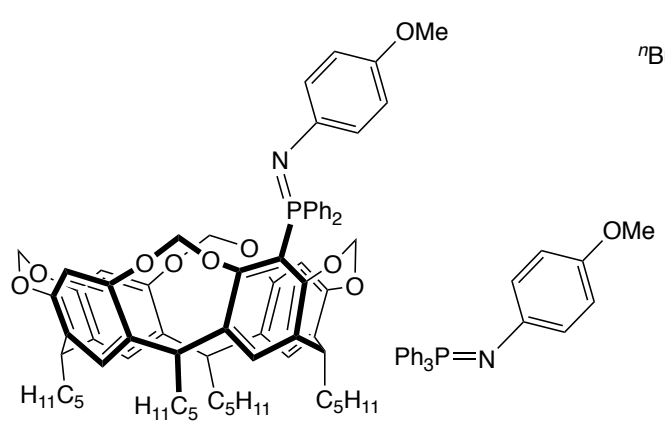

49
50

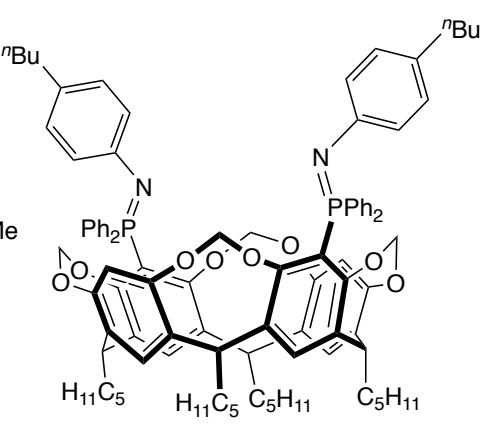

51

\begin{tabular}{|c|c|c|c|c|}
\hline Entry & $\mathrm{R}^{1} \mathrm{CH}=\mathrm{CH}_{2}$ & $\mathrm{R}^{2} \mathrm{CH}=\mathrm{CH}_{2}$ & Ligand (L/Rh) & $\begin{array}{c}\text { Hydrogenated products (\%) } \\
\mathrm{R}^{1} \mathrm{CH}_{2} \mathrm{CH}_{3} / \mathrm{R}^{2} \mathrm{CH}_{2} \mathrm{CH}_{3}\end{array}$ \\
\hline 1 & & & $47(1: 1)$ & $13.5 / 2.5=5.4$ \\
\hline 2 & & & $47(1: 2)$ & $100 / 100=1.0$ \\
\hline 3 & & & $47(2: 1)$ & $33.6 / 22.0=1.5$ \\
\hline 4 & & & $49(2: 1)$ & $35.3 / 19.5=1.8$ \\
\hline $5^{\mathrm{b}}$ & & & $50(2: 1)$ & $26.2 / 20.3=1.3$ \\
\hline $6^{\mathrm{c}}$ & & & $51(1: 1)$ & $36.4 / 22.6=1.3$ \\
\hline 7 & & & no ligand & $94.8 / 83.6=1.1$ \\
\hline
\end{tabular}

Conditions: ${ }^{[\mathrm{a}]}\left[\mathrm{Rh}(\mathrm{cod})_{2}\right] \mathrm{BF}_{4}(1 \mathrm{~mol} \%)$, ligand, olefins $\left(1.0 \mathrm{mmol}\right.$ of each), $\mathrm{P}\left(\mathrm{H}_{2}\right)=5$ bar, THF $(5 \mathrm{~mL})$, r.t., $1 \mathrm{~h}$. The conversions were determined by GC; ${ }^{[\mathrm{b}]}\left[\mathrm{Rh}(\operatorname{cod})_{2}\right] \mathrm{BF}_{4}(0.1 \mathrm{~mol}$ $\%), 50(0.2 \mathrm{~mol} \%)$, olefins (each $10.0 \mathrm{mmol}), 0.1 \mathrm{~h} ;{ }^{[\mathrm{c}]}\left[\mathrm{Rh}(\operatorname{cod})_{2}\right] \mathrm{BF}_{4}(0.1 \mathrm{~mol} \%), 51(0.1$ mol \%), olefins (each $10.0 \mathrm{mmol}$ ), $0.25 \mathrm{~h}$. 


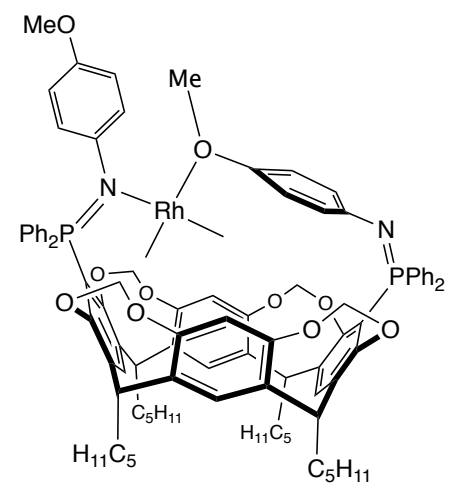

Figure 14. Proposed catalytic intermediate formed with $\mathbf{4 7}$

\section{Conclusions}

As shown in the present review, the potential of resorcinarene-derived cavitands in catalysis arises mainly from two features: i) their ability to function as ligands suitable for metal confinement and thus for making catalytic reactions either substrate selective or by increasing efficiently reaction rates through supramolecular assistance by the cavity walls; ii) their ability to create controlled steric interactions with a coordinated metal centre and/or its first coordination sphere, thereby increasing the efficiency of carbon-carbon bond forming reactions. Interestingly, their use as platforms for the attachment of different ligating sites for the generation of multifunctional ligands that may give rise to anchimeric assistance has as yet been little exploited. As generic cavitands can be easily expanded so as to provide large, bowl-shaped structures as well as capsular containers, it may be anticipated that future research in this field will focus on sophisticated microreactors (including water-soluble versions) that will enable highly selective transformations. Such chemistry has been explored with carcerand systems but the novel aspects of what is presently proposed are the ready accessibility of the cavities and the fact that the appended species are sites of catalytic activity.

\section{Acknowledgments}

We acknowledge financial support from the Institut d'Etudes Avancées de l'Université de Strasbourg (USIAS), The International Center for Frontier Research in Chemistry (icFRC), and The Indo-French Centre for the Promotion of Advanced Research (IFCPAR) (Project No 5005-1).

Keywords: Resorcinarenes · Cavitands · Catalysis · Capsules $\cdot$ Confinement 
[1] J. B. Niederl and H. J. Vogel, J. Am. Chem. Soc. 1940, 2512-2540.

[2] a) A. Baeyer, Ber. Dtsch. Chem. Ges. 1872, 5, 25-26; b) A. Baeyer, Ber. Dtsch. Chem. Ges. 1872, 5, 280-282.

[3] a) A. G. S. Högberg, J. Org. Chem. 1980, 45, 4498-4500; b) A. G. S. Högberg, J. Am. Chem. Soc. 1980, 102, 6046-6050.

[4] H. Konishi, K. Ohata, O. Morikawa and K. Kobayashi, Chem. Comm. 1995, 309-310.

[5] J. Antesberger, G. W. V. Cave, M. C. Ferrarelli, M. W. Heaven, C. L. Raston and J. L. Atwood, Chem. Commun. 2005, 892-894.

[6] B. A. Roberts, G. W. V. Cave, C. L. Raston and J. L. Scott, Green Chemistry 2001, 3, 280-284.

[7] V. K. Jain and P. H. Kanaiya, Russ. Chem. Rev. 2011, 80, 75-102.

[8] a) H. Erdtman, S. Högberg, S. A. Abrahamson and B. Nilsson, Tetrahedron Lett. 1968, 14, 1679-1682; b) B. Nilsson, Acta Chem. Scand. 1968, 22, 732-747.

[9] a) J. R. Moran, S. Karbach and D. J. Cram, J. Am. Chem. Soc. 1982, 104, 5826-5828; b) F. Weinelt and H. J. Schneider, J. Org. Chem. 1991, 56, 5527-5535; c) D. J. Cram and J. M. Cram; d) I. Thondorf, A. Shivanyuk and V. Böhmer, in Calixarenes 2001, V. Böhmer, J. Harrowfield and J. Vicens Eds., Kluwer, The Netherlands, 2001, pp 26-53; e) I. Thondorf, in Calixarenes 2001, V. Böhmer, J. Harrowfield and J. Vicens Eds., Kluwer, The Netherlands, 2001, pp 280-295.

[10] a) C. L. Raston and G. W. V. Cave, Chem. Eur. J. 2004, 10, 279-282; b) O. Ugono and K. T. Holman, Chem. Comm. 2006, 2144-2146; c) R. S. Patil, A. M. Drachnik, H. Kumari, C. L. Barnes, C. A. Deakyne and J. L. Atwood, Cryst. Growth Des. 2015, 15, 2781-2786.

[11] a) B. Q. Ma, Y. G. Zhang and P. Coppens, Cryst. Growth Des. 2002, 2, 7-13; b) A. Nakamura, T. Sato and R. Kuroda, CrystEngComm 2003, 5, 318-325; c) B. Q. Ma, L. F. V. Ferreira and P. Coppens, Org. Lett. 2004, 6, 1087-1090.

[12] R. Puttreddy, N. K. Beyeh and K. Rissanen, CrystEngComm 2016, 18, 4971-4976.

[13] R. S. Patil, C. Zhang and J. L. Atwood, Chem. Eur. J. 2016, 22, 15202-15207.

[14] A. Shivanyuk, E. F. Paulus, V. Böhmer and W. Vogt, Angew. Chem. Int. Ed. 1997, 36, 1301-1303.

[15] a) J. R. Moran, J. L. Ericson, E. Dalcanale, J. A. Bryant, C. B. Knobler and D. J. Cram, J. Am. Chem. Soc. 1991, 113, 5707-5714; b) V. A. Azov, A. Beeby, M. Cacciarini, A. G. Cheetham, F. Diederich, M. Frei, J. K. Gimzewski, V. Gramlich, B. Hecht, B. Jaun, T. Latychevskaia, A. Lieb, Y. Lill, F. Marotti, A. Schlegel, R. R. Schlittler, P. J. Skinner, P. Seiler and Y. Yamakoshi, Adv. Funct. Mater. 2006, 16, 147-156; c) D. J. Cram, Science 1983, 219, 1177-1183; d) W. Verboom, in Calixarenes 2001, V. Böhmer, J. Harrowfield and J. Vicens Eds., Kluwer, The Netherlands, 2001, pp 181-198.

[16] a) W. Xu, J. P. Rourke, J. J. Vittal and R. J. Puddephatt, Inorg. Chem. 1995, 34, 323-329; b) P. Sakhaii, I. Neda, M. Freytag, H. Thönnessen, P. G. Jones and R. Schmutzler, Z. Anorg. Allg. Chem. 2000, 626, 1246-1254; c) R. Pinalli, M. Suman and E. Dalcanale, Eur. J. Org. Chem. 2004, 451-462; d) R. J. Puddephatt, Can. J. Chem. 2006, 84, 1505-1514; e) J. Vachon, S. Harthong, B. Dubessy, J. P. Dutasta, N. Vanthuyne, C. Roussel and J. V. Naubron, Tet. Asymmetry 2010, 21, 1534-1541.

[17] S. N. Parulekar, K. Muppalla, F. R. Fronczek and K. S. Bisht, Chem. Comm. 2007, 49014903.

[18] D. Masseroni, S. Mosca, M. P. Mower, D. G. Blackmond and J. Rebek, Angew. Chem. Int. Edit. 2016, 55, 8290-8293.

[19] M. Kanaura, N. Endo, M. P. Schramm and T. Iwasawa, Eur. J. Org. Chem. 2016, 49704975. 
[20] D. J. Cram and J. M. Cram, Container Molecules and their Guests, monographs in Supramolecular Chemistry, No.4, J. F Stoddart, Series Editor, Royal Society of Chemistry, Cambridge, 1994, Ch. 6, pp.107-130.

[21] a) S. M. Butterfield and J. Rebek, Chem. Commun. 2007, 1605-1607; b) E. Biavardi, G. Battistini, M. Montalti, R. M. Yebeutchou, L. Prodi and E. Dalcanale, Chem. Commun. 2008, 1638-1640; c) T. V. Nguyen, D. J. Sinclair, A. C. Willis and M. S. Sherburn, Chem. Eur. J. 2009, 15, 5892-5895; d) S. Javor and J. Rebek, J. Am. Chem. Soc. 2011, 133, 17473-17478.

[22] a) D. J. Cram, S. Karbach, Y. H. Kim, L. Baczynskyj and G. W. Kalleymeyn, J. Am. Chem. Soc. 1985, 107, 2575-2576; b) P. Timmerman, M. G. A. van Mook, W. Verboom, G. J. Vanhummel, S. Harkema and D. N. Reinhoudt, Tet. Lett. 1992, 33, 3377-3380; c) P. Jacopozzi and E. Dalcanale, Angew. Chem. Int. Edit. 1997, 36, 613-615; d) R. Warmuth, J. Incl. Phenom. Macrocyclic Chem. 2000, 37, 1-38; e) J. Sherman, Chem. Comm. 2003, 16171623; f) R. J. Hooley and J. Rebek, Chem Biol. 2009, 16, 255-264.

[23] S. Mendoza, P. D. Davidov and A. E. Kaifer, Chem. Eur. J. 1998, 4, 864-870.

[24] a) J. Gout, A. Vis`njevac, S. Rat, O. Bistri, N. Le Poul, Y. Le Mest and O. Reinaud, Eur. J. Inorg. Chem. 2013, 2013, 5171-5180; b) D. Sémeril and D. Matt, Coord. Chem. Rev. 2014, 279, 58-95; c) J. Gout, S. Rat, O. Bistri and O. Reinaud, Eur. J. Inorg. Chem. 2014, 2014, 2819-2828.

[25] a) J. C. Sherman, Tetrahedron 1995, 51, 3395-3422; b) C. Naumann and J. C. Sherman, in Calixarenes 2001, V. Böhmer, J. Harrowfield and J. Vicens Eds., Kluwer, The Netherlands, 2001, pp 199-218.

[26] P. Roncucci, L. Pirondini, G. Paderni, C. Massera, E. Dalcanale, V. A. Azov and F. Diederich, Chem. Eur. J. 2006, 12, 4775-4784.

[27] R. Gramage-Doria, D. Armspach and D. Matt, Coord. Chem. Rev. 2013, 257, 776-816.

[28] a) G. Arnott, H. Heaney, R. Hunter and P. C. B. Page, Eur. J. Org. Chem. 2004, 51265134; b) L. Ngodwana, S. Bose, V. Smith, W. A. L. van Otterlo and G. E. Arnott, Eur. J. Inorg. Chem. DOI: 10.1002/ejic.201601424 2017.

[29] C. Gibson and J. Rebek Jr., Org. Lett. 2002, 4, 1887-1890.

[30] H. El Moll, D. Sémeril, D. Matt and L. Toupet, Adv. Synth. Catal. 2010, 352, 901-908.

[31] H. El Moll, D. Sémeril, D. Matt, M. T. Youinou and L. Toupet, Org. Biomol. Chem. 2009, 7, 495-501.

[32] M. Feuerstein, H. Doucet and M. Santelli, J. Org. Chem. 2001, 66, 5923-5925.

[33] L. Monnereau, H. El Moll, D. Sémeril, D. Matt and L. Toupet, Eur. J. Inorg. Chem. 2014, 2014, 1364-1372.

[34] a) T. Chavagnan, D. Sémeril, D. Matt, J. Harrowfield and L. Toupet, Chem. Eur. J. 2015, 21, 6678-6681; b) T. Chavagnan, D. Sémeril, D. Matt, L. Toupet, J. Harrowfield and R. Welterd, Eur. J. Inorg. Chem. 2016, 497-502.

[35] a) P. Thordarson, E. J. A. Bijsterveld, A. E. Rowan and R. J. M. Nolte, Nature 2003, 424, 915-918; b) D. Sémeril, C. Jeunesse, D. Matt and L. Toupet, Angew. Chem. Int. Ed. 2006, 45, 5810-5814; c) M. Jouffroy, R. Gramage-Doria, D. Sémeril, D. Armspach, D. Matt, W. Oberhauser and L. Toupet, Beilstein J. Org. Chem. 2014, 10, 2388-2405; d) M. Teci, E. Brenner, D. Matt, C. Gourlaouen and L. Toupetc, Dalton Trans. 2015, 44, 9260-9268; e) M. Teci, N. Lentz, E. Brenner, D. Matt and L. Toupet, Dalton Trans. 2015, 44, 13991-13998; f) M. Jouffroy, D. Armspach, D. Matt, K. Osakada and D. Takeuchi, Angew. Chem. Int. Edit. 2016, 55, 8367-8370.

[36] N. Endo, M. Kanaura, M. P. Schramm and T. Iwasawa, Tet. Lett. 2016, 57, 4754-4757.

[37] N. Endo, M. Kanaura, M. P. Schramm and T. Iwasawa, Eur. J. Org. Chem. 2016, 25142521.

[38] M. P. Schramm, M. Kanaura, K. Ito, M. Ide and T. Iwasawa, Eur. J. Org. Chem. 2016, 813-820. 
[39] W. Śliwa, Arkivoc 2006, 137-159.

[40] a) Y. Cohen, L. Avram and L. Frish, Angew. Chem. Int. Ed. 2005, 44, 520-554; b) D. Zuccaccia, L. Pirondini, R. Pinalli, E. Dalcanale and A. Macchioni, J. Am. Chem. Soc. 2005, 127, 7025-7032.

[41] A. Lledó, S. Kamioka, A. C. Sather and J. Rebek, Angew. Chem. Int. Ed. 2011, 50, 12991301.

[42] F. Corbellini, F. W. B. van Leeuwen, H. Beijleveld, H. Kooijman, A. L. Spek, W. Verboom, M. Crego-Calama and D. N. Reinhoudt, New J. Chem. 2005, 29, 243-248.

[43] T. Chavagnan, D. Sémeril, D. Matt and L. Toupet, Eur. J. Org. Chem. 2017, 313-323.

[44] H. El Moll, D. Sémeril, D. Matt, L. Toupet and J. J. Harrowfield, Org. Biomol. Chem. 2012, 10, 372-382.

[45] a) S. K. Kim, B. G. Kang, H. S. Koh, Y. J. Yoon, S. J. Jung, B. Jeong, K. D. Lee and J. Yoon, Org. Lett. 2004, 6, 4655-4658; b) S. K. Kim, B. S. Moon, J. H. Park, Y. Seo, H. S. Koh, Y. J. Yoon, K. D. Lee and J. Yoon, Tetrahedron Lett. 2005, 46, 6617-6620; c) W. W. H. Wong, M. S. Vickers, A. R. Cowley, R. L. Paul and P. D. Beer, Org. Biomol. Chem. 2005, 3, 4201-4208.

[46] N. Şahin, D. Sémeril, E. Brenner, D. Matt, I. Özdemir, C. Kaya and L. Toupet, Chem CatChem 2013, 5, 1116-1125.

[47] M. Kaloğlu, D. Sémeril, E. Brenner, D. Matt, I. Özdemir and L. Toupet, Eur. J. Inorg. Chem. 2016, 1115-1120.

[48] M. G. Organ, M. Abdel-Hadi, S. Avola, N. Hadei, J. Nasielski, C. J. O'Brien and C. Valente, Chem. Eur. J. 2007, 13, 150-157.

[49] N. Şahin, D. Sémeril, E. Brenner, D. Matt, C. Kaya and L. Toupet, Turk. J. Chem. 2015, 39, 1171-1179.

[50] N. Şahin, D. Sémeril, E. Brenner, D. Matt, I. Özdemir, C. Kaya and L. Toupet, Eur. J. Org. Chem. 2013, 2013, 4443-4449.

[51] M. Kaloğlu, N. Şahin, D. Sémeril, E. Brenner, D. Matt, I. Özdemir, C. Kaya and L. Toupet, Eur. J. Org. Chem. 2015, 7310-7316.

[52] T. Chavagnan, C. Bauder, D. Sémeril, D. Matt and L. Toupet, Eur. J. Inorg. Chem. 2017, 70-76. 